\title{
norden
}

\section{The Nordic Aichi restoration project}

How can the Nordic countries implement the CBD-target on restoration of $15 \%$ of degraded ecosystems within 2020 ? 

2 norden 



\section{The Nordic Aichi restoration project}

How can the Nordic countries implement the CBD-target on restoration of $15 \%$ of degraded ecosystems within 2020?

Dagmar Hagen, Anna Lindhagen, Jussi Päivinen, Kristín Svavarsdóttir, Margit Tennokene, Terje Klokk and Maja Stade Aarønæs 
The Nordic Aichi restoration project

How can the Nordic countries implement the CBD-target on restoration of $15 \%$ of degraded ecosystems within 2020 ?

Dagmar Hagen, Anna Lindhagen, Jussi Päivinen, Kristín Svavarsdóttir, Margit Tennokene, Terje Klokk and Maja Stade Aarønæs

ISBN 978-92-893-3974-2 (PRINT)

ISBN 978-92-893-3976-6 (PDF)

ISBN 978-92-893-3975-9 (EPUB)

http://dx.doi.org/10.6027/TN2015-515

TemaNord 2015:515

ISSN 0908-6692

(C) Nordic Council of Ministers 2014

Layout: Hanne Lebech

Cover photo: Kristín Svavarsdóttir

Printed in Denmark

This publication has been published with financial support by the Nordic Council of Ministers. However, the contents of this publication do not necessarily reflect the views, policies or recommendations of the Nordic Council of Ministers.

\section{www.norden.org/en/publications}

\section{Nordic co-operation}

Nordic co-operation is one of the world's most extensive forms of regional collaboration, involving Denmark, Finland, Iceland, Norway, Sweden, and the Faroe Islands, Greenland, and Åland.

Nordic co-operation has firm traditions in politics, the economy, and culture. It plays an important role in European and international collaboration, and aims at creating a strong Nordic community in a strong Europe.

Nordic co-operation seeks to safeguard Nordic and regional interests and principles in the global community. Common Nordic values help the region solidify its position as one of the world's most innovative and competitive.

\section{Nordic Council of Ministers}

Ved Stranden 18

DK-1061 Copenhagen K

Phone (+45) 33960200

www.norden.org 


\section{Content}

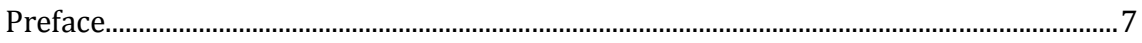

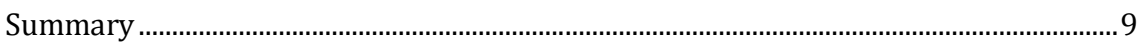

Part 1: Setting the scene ............................................................................................... 11

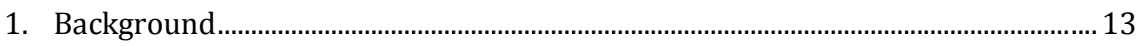

1.1 CBD and the Nordic commitment................................................................. 13

1.2 The aim and structure of the report ................................................................. 14

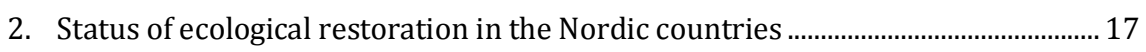

Part 2: How to proceed towards the 15\% target? .............................................................. 23

3. The EU 4-level model for ecosystem restoration...................................................... 25

$3.1 \quad$ Background and structure of the conceptual model......................................25

3.2 Assumptions and challenges for taking the model further ........................... 28

3.2.1 How to set the baseline and reference point? ....................................... 28

3.2.2 How to define descriptors and threshold values? ................................ 29

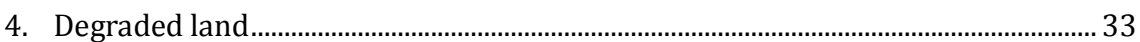

4.1 The concept of degradation and degraded land ...................................................... 33

4.2 Degraded land in the Nordic countries and Estonia .......................................... 36

4.3 Considerations for the $15 \%$ target approach ................................................... 46

4.3.1 Comparing levels and degraded state between countries ................. 46

4.3.2 A net $15 \%$ - new disturbed areas must be deducted from any progress................................................................................................. 47

4.3.3 Implications of using 2010 as a reference year..................................... 49

5. Restoration for the reduction of degraded land........................................................ 51

5.1 Are all restoration activities relevant for the Aichi targets? .........................53

5.2 How to measure progress and to find the best descriptors?.......................... 55

5.3 Achievements and progress of restoration in the Nordic countries

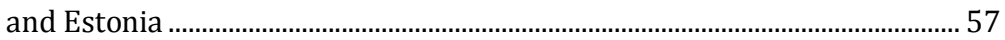

6. Input for further work on national level and in local communities .......................... 61

6.1 National programs and individual, local projects must work

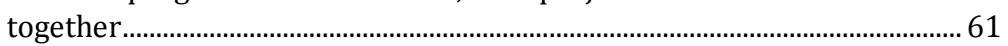

6.2 Alternative way to achieve the target - the Finnish way ................................6 63

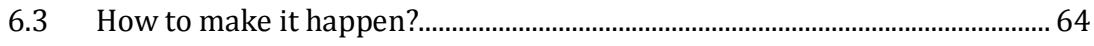

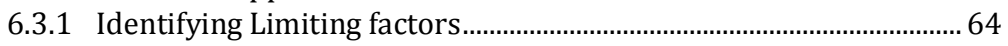

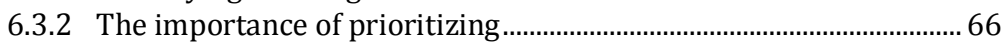

7. Actions for more effective restoration in the Nordic countries and Estonia...........69

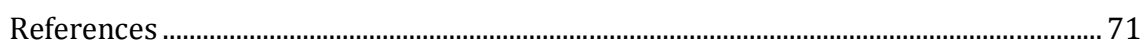

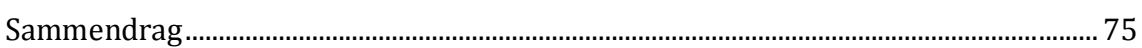





\section{Preface}

In 2010 the Convention of Biological Diversity formulated 20 strategic targets for 2020 towards halting the loss of biodiversity, called the Aichitargets. In particular two of these targets address the need for the restoration of degraded land. The Nordic countries are committed to the CBD and the Aichi targets. The status and need for restoration of degraded land has been documented worldwide, including in this part of the world.

The Terrestrial Ecology Group (TEG) under the Nordic Council of Ministers have given priority to a project to address these implications, and to formulate how the Nordic countries should work towards achievements of the Aichi targets on restoration of degraded land. The project was presented at the SER (Society of Ecological Restoration) 2014 European Conference in Oulu, 3rd-8th August, in the session "EU 2020 biodiversity strategy and 15\% Restoration target."

The project has made use of the assessment and evaluation of Nordic restoration done by the previous TEG project "Restoration in the Nordic countries - ReNo" (2009-2011) and the ongoing "Evaluation of Restoration in the North" (2012-2014), financed by the Co-operation between the Nordic Council of Ministers and neighbours to the west. Also, the EU project in which the conceptual 4-level model of ecosystem restoration within the EU biodiversity strategy from "Green Infrastructure and Restoration Prioritization Framework Working Group" has been useful for the current project.

The project concludes with seven actions of relevance for the Nordic countries in the further work. It has a pragmatic and realistic approach to these complex issues, and it should be stressed that the role of the work has not been to provide detailed procedures on how the countries should achieve the 2020 targets on restoration, but rather to review the situation and identify possible ways to progress. 
The work is very much in line with the emphasis the ministers of Environment lay on the challenge of restoration of degraded land, which is reflected in the Environment Action Plan 2013-2018.

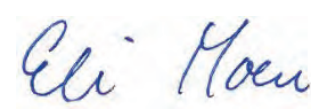

Eli Moen

Deputy Director General

Department for Nature Management

Norwegian Ministry of Climate and Environment 


\section{Summary}

The Nordic Aichi restoration project

How can the Nordic countries implement the CBD-target on restoration of $15 \%$ of degraded ecosystems within 2020?

The Convention of Biological Diversity commits the parties to halt the loss of biodiversity within 2020. For accomplishing this task, 20 targets, so called Aichi targets, have been formulated of which two aim directly at restoring degraded land. This is most specifically stated in target 15, which aims at restoring $15 \%$ of damaged ecosystems by 2020 . Ecological restoration is defined as "the process of assisting the recovery of an ecosystem that has been degraded, damaged, or destroyed," relating the recovery to health, integrity and sustainability of ecosystems. The Nordic countries are parties of CBD, and are committed to the Aichi targets, and each country also has national environmental targets that corresponds with these international commitments. The current project is set within the traditional Nordic frame and the interest for cooperation and common intentions regarding environmental issues.

The aim of this project is to establish a basis for management and political authorities in the Nordic countries for the achievement of Aichi target 15 on restoration of degraded ecosystems. The report addresses the possibilities, limitations and challenges for how ecological restoration can contribute to the Aichi targets, based on available knowledge and existing statistics on degraded land and restoration experiences in the Nordic countries and Estonia. This is intended as a contribution to future work at the national and in local communities.

The input from the project "Restoration in the Nordic countries", supported by the Nordic Council of Ministers and TEG (2009-2011) gave an overview of ongoing restoration activities on a Nordic regional scale and was an important source to build on for the current project. In addition, the EU project in which the conceptual 4-level model of ecosystem restoration within the EU biodiversity strategy was developed has been useful for this Nordic Aichi project.

The concept of degraded land is essential to measure the progress towards the $15 \%$ target. We have explored if available statistics can be used to allocate numbers for different levels of degraded land for countries and habitats. As the data are based on different statistics and dif- 
ferent definitions of degraded levels they cannot be adopted as the current status, more as an indication. Furthermore, they have limited value for comparison between countries. However, if given priority, this can be further developed and perhaps standardized for the purpose.

Identification of relevant descriptors and indicators is critical to report progress of restoration. We have assessed if existing data and statistics on restored land in the Nordic countries and Estonia are suitable, and partly looked into what descriptors and indicators are reported. Available knowledge and data on restoration derive from: (1) General and broad scale national databases and statistics, and (2) data on individual (small and large) projects. The need for coordinated work of national initiatives and strategies in combination with individual projects in local communities is striking, and should be developed into a "top-down and bottom-up" strategy for restoration. The lack of data on restoration activities and progress was obvious. We believe however that it was relevant to compile this insufficient overview in order to increase awareness about the deficiency of data and for promoting enhanced cooperation between countries to improve existing statistics, identify missing data, and encourage the use of the available data as a basis for future restoration strategies. Finland is so far the only Nordic country with an established national board for restoration prioritization, and will by the end of 2015 propose a national restoration prioritization strategy related to the $15 \%$ target. The other countries should be informed about the progress and may find inspiration from Finland for their own development of national strategies.

The project has listed seven actions of relevance for the Nordic countries and Estonia in the further work towards more effective restoration: 1. A progress towards the Aichi 15 target calls for a clear vision and national plans for ecological restoration; 2. In a situation of limited resources for restoration it is essential to develop good models for priority setting; 3. Integration and cooperation is needed to formulate realistic goals for restoration, and restoration must be integrated into all sectors of land-use management; 4 . The focus must be on restoration activities and output, so $15 \%$ itself must not take the focus away from what this really is about: to reduce ecosystem degradation and to head towards improved and more ecological restoration; 5 . More and improved restoration will need initiatives at the national level (as strategic plans and programs) and integration of all the local initiatives, and these should be made into a top-down and bottom up approach; 6 . Procedures to identify limiting factors is essential for effective restoration, and should be developed for countries/habitats; 7. Measurable descriptors for producing statistics on progress of restoration must be developed. 
Part 1:

Setting the scene 



\section{Background}

\subsection{CBD and the Nordic commitment}

The Convention of Biological Diversity commits the member countries to stop the loss of biodiversity within 2020, and for accomplishing this task 20 Aichi targets have been formulated, named after the Japanese town where they were agreed. ${ }^{1}$ These targets are formulated within the frame of five strategic goals: A - Address the underlying causes of biodiversity loss by mainstreaming biodiversity across government and society, B Reduce the direct pressures on biodiversity and promote sustainable use, C - To improve the status of biodiversity by safeguarding ecosystems, species and genetic diversity, D - Enhance the benefits to all from biodiversity and ecosystem services. E - Enhance implementation through participatory planning, knowledge management and capacity building.

Two of the 20 targets aim directly at restoring degraded land. This is most specifically stated in target 15 , which aims at restoring $15 \%$ of damaged ecosystems by 2020 . Restoration also has obvious links to other strategic targets aiming at sustainability, conservation, knowledge building and policy, including target 5 on fragmented habitats and target 9 on alien species.

The strategy for sustainable development in the Nordic countries for 2013 focused on the importance of vigorous ecosystems, with a link to the CBD (Nordiska ministerrådet 2013). The EU strategy for biological diversity includes similar targets and is in particular relevant for those Nordic countries that are EU members. ${ }^{2}$ All the Nordic countries are members of CBD, and are committed to the Aichi targets. Each country has national environmental targets that corresponds with international commitments, and the achievement of the Aichi targets is a part of this agenda.

\footnotetext{
${ }^{1}$ http://www.cbd.int/doc/strategic-plan/2011-2020/Aichi-Targets-EN.pdf

2 http://ec.europa.eu/environment/nature/biodiversity/comm2006/2020.htm
} 


\section{Aichi target 14}

"ecosystems that provide essential services ... and contribute to health, livelihoods and well-being, are restored and safeguarded ...".

\section{Aichi target 15}

"by 2020, ecosystem resilience and the contribution of biodiversity to carbon stocks has been enhanced, through conservation and restoration, including restoration of at least 15 per cent of degraded ecosystems, thereby contributing to climate change mitigation and adaptation and to combating desertification".

During the last decade ecological restoration has been acknowledged in regional and global policy and in science as a needed and urgent activity for reversing the level of degraded land, and a tool for future nature management and support of ecosystem services (Benayas et al. 2009, Comín 2010, Bullock et al. 2011, Suding 2011). Ecological restoration is "the process of assisting the recovery of an ecosystem that has been degraded, damaged, or destroyed," relating to the recovery of ecosystem health, integrity and sustainability (SER 2004). The concept will be further elaborated in chapter 5 .

\subsection{The aim and structure of the report}

The aim of this project is to establish a basis for management and political authorities in the Nordic countries for the achievement of CBDtarget (Aichi-target) 15 on restoration of degraded ecosystems. This target addresses a broad number of topics, such as ecosystem resilience, carbon storage, and conservation. In this project the emphasis has been limited to restoration, and we will address the possibilities, limitations and challenges for how restoration can contribute to the Aichi targets, based on available knowledge and existing statistics on degraded land and restoration experiences in the Nordic countries and Estonia. This is intended to contribute to future work on a national level and in local communities.

The work has been organized within a project working group established in June 2013 with representatives from governmental institutions in Sweden (Anna Lindhagen, Swedish Environmental Protection Agency), Finland (Jussi Päivinen, Metsähallitus), Iceland (Kristín Svavarsdóttir, Soil Conservation Service of Iceland), Norway (Terje Klokk/Maja Stade Aarønæs, Norwegian Environmental Agency, project manager), 
and Estonia (Margit Tennokene, Environmental Ministry of Estonia). Dagmar Hagen (Norway, Norwegian Institute for Nature Research) worked as the secretary of the project.

The structure of the report follows the approach of the project. We give a brief overview of the status of restoration in the Nordic countries and Estonia, mainly based on the work from the ReNo-group. An EU working group established to support the Biodiversity strategy finished its work with a conceptual model for how the EU could work towards the 15\% target. As the Nordic EU countries and Estonia already had contributed to the EU-work, and the output from this group was considered relevant for all countries, it was reasonable to use this as a basis for the Nordic project. We give an overview of the 4-level model and discuss its consequences and challenges in chapter 3 . Further we discuss the concept of degraded land within a northern frame, as a broad understanding of this is essential for the formulation of aim and for measuring the progress of restoration, and for priorities of actions. Then we go more specifically into restoration of land, and put special attention to some complicated issues that must be overcome to measure progress towards the $15 \%$ target. Issues discussed are whether all types of restoration are relevant, what is restorable land, and the relationship between management and restoration. We also elaborate on how ongoing restoration work can contribute to the restoration of land, with a special focus on how to measure the progress of restoration, what parameters are relevant, and not least the assessment of available statistics of restored land. We briefly discuss the relationship between local projects and national programs and address the relevance of identifying limiting factors for restoration. We also give a short overview of a 10-step model developed for the restoration prioritizing process in Finland. Finally, we suggest some actions for more effective restoration towards achievement of the $15 \%$ target.

The Nordic countries have a tradition of and interest for cooperation regarding environmental issues, "together the Nordic Region can contribute input and knowledge sharing at international environmental conventions and other forms of international cooperation" (Nordic Environmental Action Plan 2009-2012 and Nordic Environmental Action Plan 2013-2018). In this plan one of the priorities is "exchanging information and cooperation on the possible restoration of damaged ecosystems". The project works within this frame of cooperation and common intentions, and the networking and sharing of knowledge is also a relevant output of this project. 



\section{Status of ecological restoration in the Nordic countries}

During 2009-2011 Nordic Council of Ministers and TEG supported the project "Restoration in the Nordic countries" (ReNo). This was the first attempt to gather overview and create a network amongst ecological restorationist on a Nordic regional scale. A total of 13 Nordic institutions were involved in the ReNo network, including the scientific community, public and private organizations and NGO's working on ecological restoration (Halldórsson et al. 2012).

The primary tasks of the network were to assess and present the ecological restoration activities in the Nordic countries and consolidate information on ecological restoration in the region. The countries differed in their approaches, depending on present status and knowledge. The Faroe Islands, Iceland and Norway published national assessments of restoration activities (Hagen \& Skrindo 2010, Aradóttir \& Halldórsson 2011, Fosaa \& Simonsen 2011), while the EU-countries Denmark, Finland and Sweden already had information about large restoration projects as a part of final reports to the EU-LIFE Nature program. Analyses of EU-LIFE Nature ecological restoration projects were conducted in Denmark (Morsing et al. 2013) and Sweden (Johansson 2011). Finland produced guidebooks of forest restoration (Similä \& Junninen 2011, Similä \& Junninen 2012) and peatland restoration (Aapala et al. 2012, Aapala et al. 2014) in conjunction with the ReNo network.

All details about the work and outcome from the ReNo-project are presented in the final report (Halldórsson et al. 2012). In addition a special feature of the journal Ecology \& Society was published in 2013 with 12 scientific papers and a number of them emphasized on Nordic case studies. ${ }^{3}$ Below we briefly sum up the status in each country and the main conclusions from an analysis comparing and contrasting countries, based on the

${ }^{3}$ http://www.ecologyandsociety.org/issues/view.php/feature/82 
text from Halldórsson et al. (2012, p. 15-21) together with some updated information. The natural conditions, scale and types of restoration activities are quite different between the countries (Figure 2 a-e). To get a comparable overview of restoration in the Nordic region activities were divided into habitats, i.e. restoration of natural forests, wetlands/peatlands, freshwater systems, heathlands/natural grasslands and cultural landscapes.

Denmark is the smallest of the Nordic countries and also the country with most intensive land-use. Consequently, the restoration is in general more a transition into more "nature friendly" management practice rather than strict ecological restoration (Morsing et al. 2013). Most restoration activities are related to abandoned agricultural land and wetlands (Hagen et al. 2013). The largest restoration project in Denmark is the restoration of the Skjern River (Pedersen et al. 2007). Denmark has not been a part of the current project.

The Faroe Islands was a part of the ReNo-project, however restoration activities are restricted to some minor wetland projects (Fosaa \& Simonsen 2011). The Faroe Islands has not been a part of the current project.

Finland has high focus on restoration of natural forests and peatlands, and has so far restored more than $200 \mathrm{~km}^{2}$ of forests and $200 \mathrm{~km}^{2}$ of peatlands, mainly on state owned and protected land (Similä \& Junninen 2012, Aapala et al. 2014, Päivinen pers. comm.). Also the management of semi-natural grassland is an important activity in Finland. The largest restoration project in Finland is Boreal Peatland Life, which aims at restoring nearly $43 \mathrm{~km}^{2}$ of peatlands (Hagen et al. 2013).

Iceland has a long history of land degradation and soil erosion and has over 100 year's history of land reclamation (Aradottir et al. 2013). So far more than $1,500 \mathrm{~km}^{2}$ of heathland/grassland and $200 \mathrm{~km}^{2}$ of native birch woodlands have been restored and some wetland restoration projects exist. The largest ecological restoration project is the Hekluskogar project, which aims at restoring native woodland on ca. $900 \mathrm{~km}^{2}$ of eroded land in the vicinity of the volcano Mt Hekla (Óskarsson 2009).

Restoration is quite a novel activity in Norway, but during the last decades restoration projects have been done in cultural landscapes (semi-cultural vegetation), freshwater systems and heathland/natural grassland. A national plan for restoration of wetlands has been developed by the Environmental Agency. The largest ecological restoration project in Norway is HjerkinnPRO, the restoration of a former military training area $\left(165 \mathrm{~km}^{2}\right)$ in the alpine zone (Hagen \& Evju 2013).

Sweden has not prioritized restoration of certain habitats. For aquatic habitats, most restoration activities have been carried out in rivers and streams. For wetlands important measures have been recreation and 
restoration of wetlands in agricultural areas, and restoration of mires and bogs by "plugging" artificial drainage. For semi-natural grassland, priority has been given to restoration of semi-natural meadows and pastures, mainly financed by the EU Rural Development Program, or by the LIFE fund in protected areas. In forests, priority actions include prescribed burnings, restoration of hydrology and actions aiming at improving habitats for species. Many of the largest restoration projects have been co-financed by the EU LIFE fund.

Estonia was not a part of the ReNo-project, so the status for restoration has been summarized for the purpose of the present project. Restoration efforts in Estonia are mainly directed towards wetlands and seminatural grasslands. During the Soviet era over half of the wetlands in Estonia were drained for forestry and agricultural purposes. Land use is mainly divided between forestry and agriculture and in some parts forestry has left areas fragmented and implementation of Green Infrastructure has not been satisfactory. One third of the clearcut areas are actively reforested for timber management.

The analysis of ongoing restoration in the Nordic region shows that the typical main land-use pressures (like agriculture, forestry, overgrazing, infrastructure development, urbanization and alien species) are found in the most common habitats and cause need for restoration. However, in some habitat types the actual restoration activity is limited despite high pressure and obvious need for restoration. This indicates that other factors than land-use pressure determines the priorities and efforts for restoration (Hagen et al. 2013). When comparing methods used in restoration within each habitat, similar methods are used amongst the countries, reflecting the limited number of tools available (and perhaps needed) for actually doing the interventions (Hagen et al. 2013). From this it is possible to conclude that habitat types determine the methods used for ecological restoration (how to do restoration), whereas socio-economic drivers are more important for decisions concerning the timing and location of restoration (where and when to do restoration).

The final report from the ReNo-project concluded that the network had consolidated knowledge on ecological restoration work in the Nordic region and facilitated exchange of this knowledge within and between the Nordic countries (Halldórsson et al. 2013). The products from the ReNo-project have given essential inputs for this Nordic Aichiproject on restoration. 
Figure 2a: Peatland restoration by mulch and seeding in Estonia

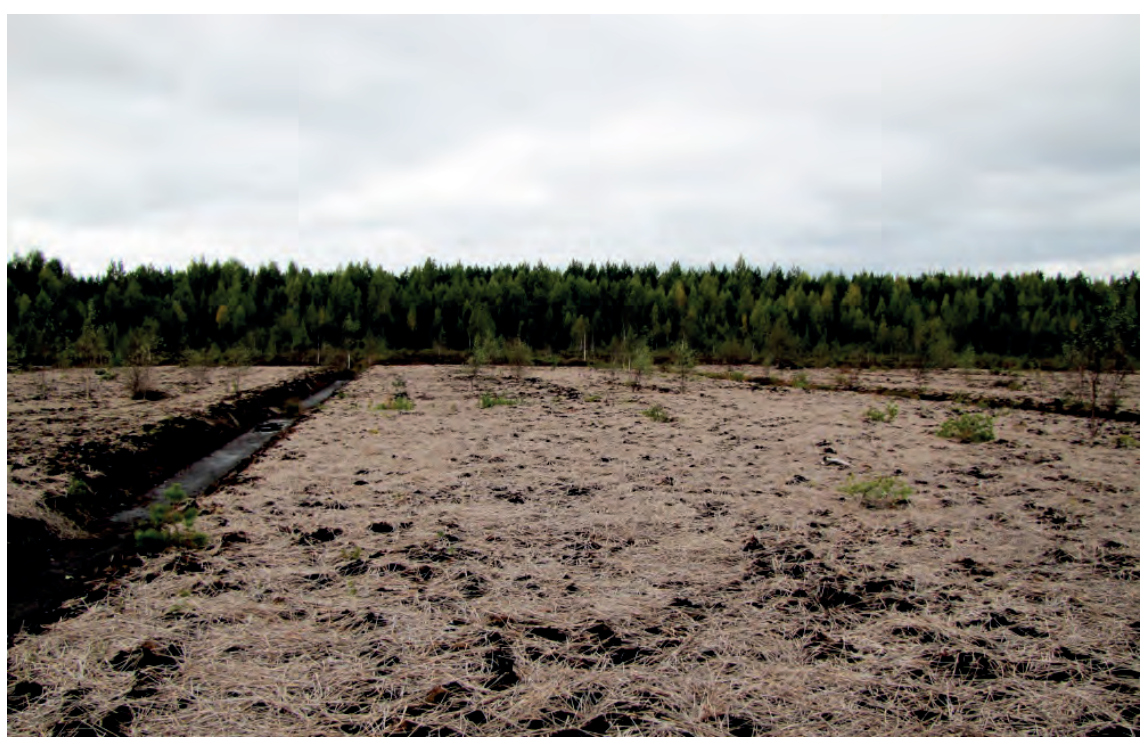

Photo: Margit Tennokene.

Figure 2b: Creation of dead wood in Finland. A polypore (Fomitopsis pinicola) has colonized a dead scots pine that was killed by chainsaw

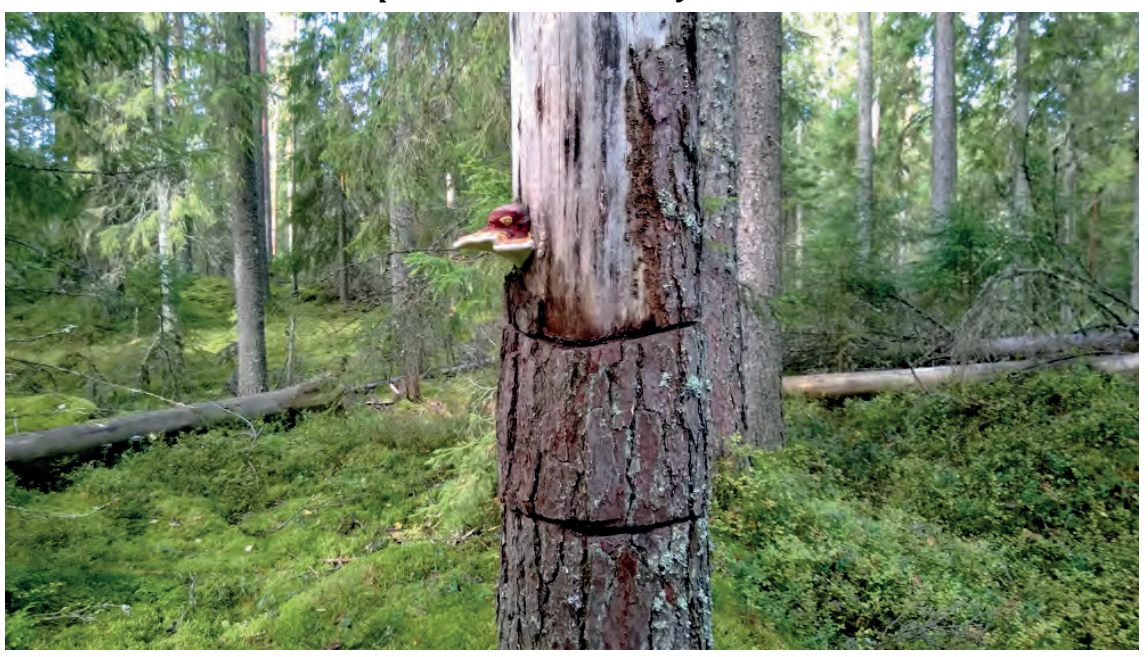

Photo: Jussi Päivinen. 
Figure 2c: In Iceland the first step of restoring eroded land can be seeding grasses to stabilize the soil surface.

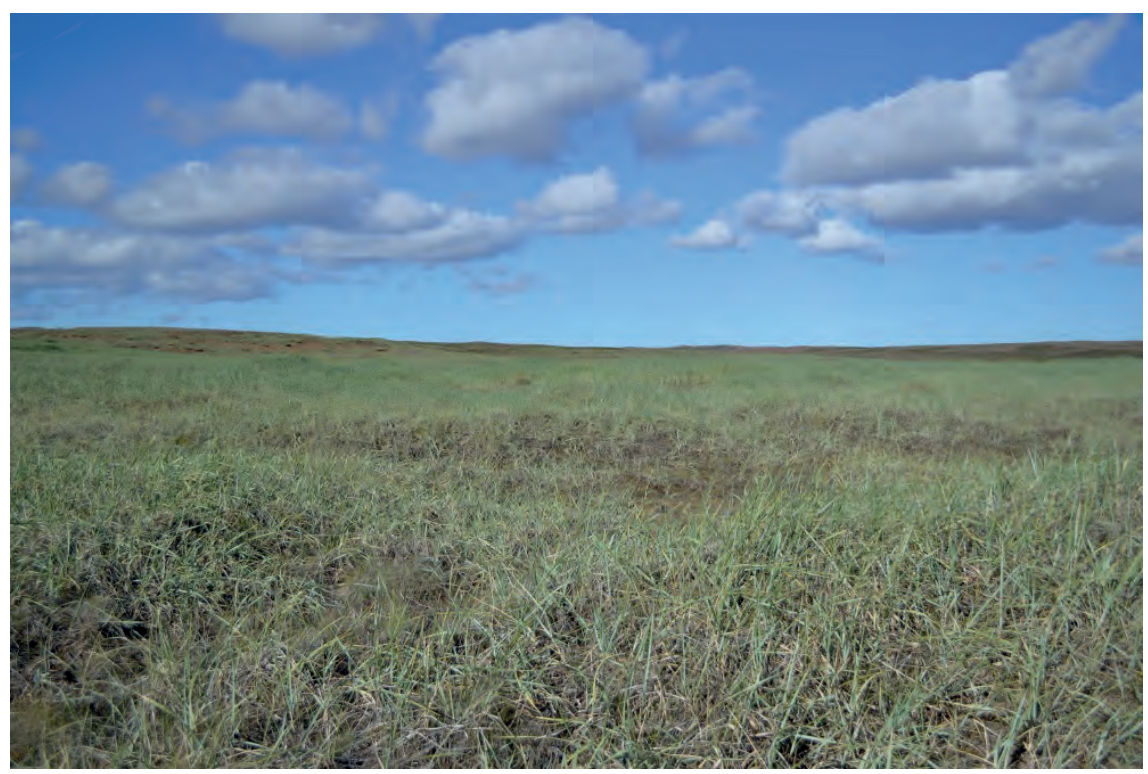

Photo: Kristín Svavarsdóttir.

Figure 2d: Restoring alpine heathland by turfs to facilitate natural recovery in central Norway

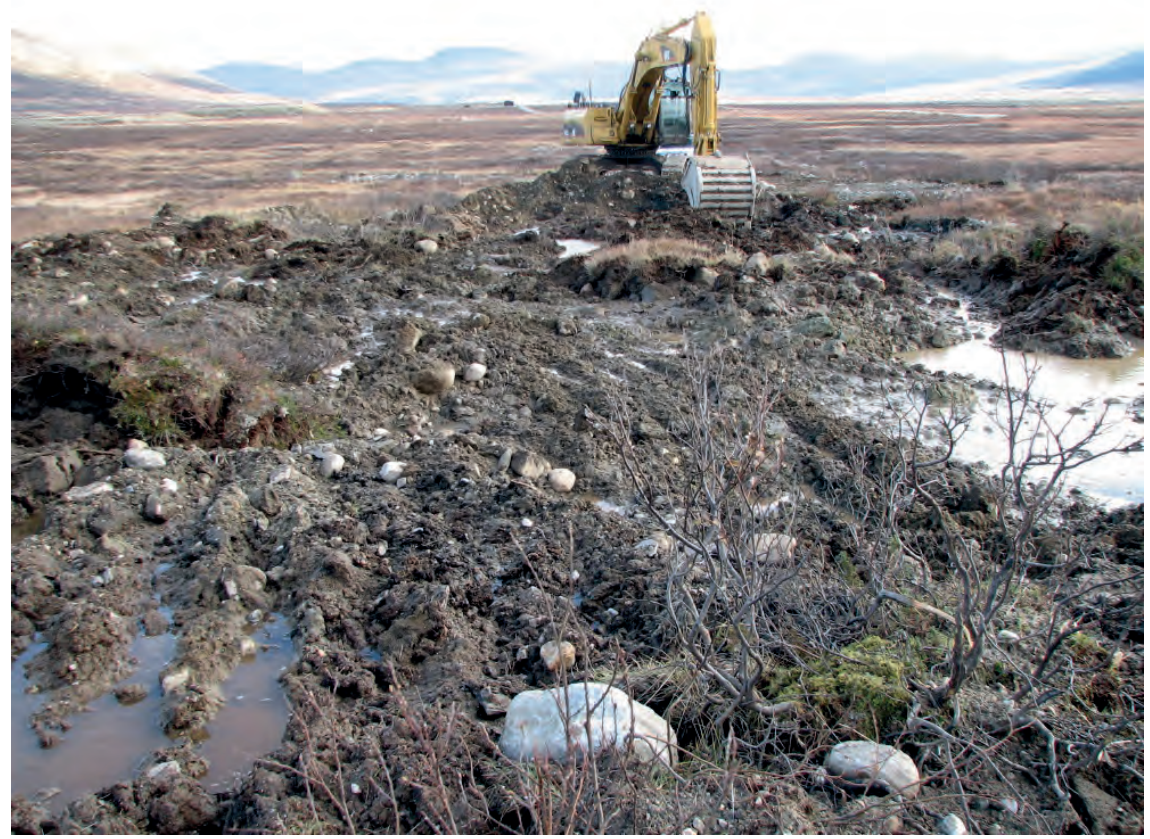

Photo: Dagmar Hagen. 
Figure 2e: Burning is a method to restore species habitat in boreal forests in Sweden and Finland

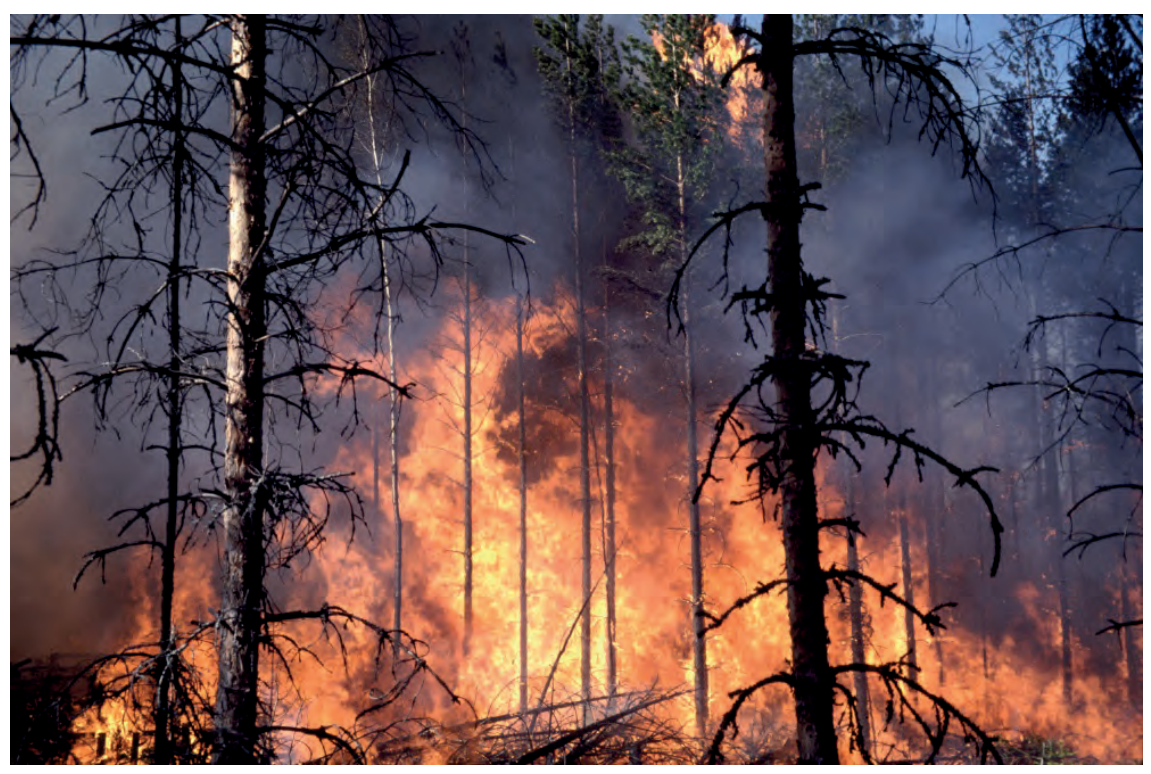

Photo: Anneli Suikki. 


\section{Part 2:}

\section{How to proceed towards the $15 \%$ target?}

\footnotetext{
Working towards the Aichi targets call for good plans, systematic and long-term work, utilizing existing data and developing new knowledge and solutions when needed. The EU work towards a 4-level model for ecosystem restoration is a response to this, as it describes and suggests a systematic approach, and raises some fundamental questions and challenges. The concept and available statistics on degraded land is the basis for measuring progress of restoration, and we have assessed this within the frame of the 4level model for the Nordic countries and Estonia, to illustrate the potential and limitations. Active restoration efforts over large areas are needed to proceed towards the $15 \%$ target, and this call for both national strategies and a diversity of small projects in all degraded habitats. We have assessed available data on ongoing restoration from the Nordic countries and Estonia, and discussed this within the frame of further work and how to set up good plans and schemes for future restoration.
} 



\section{The EU 4-level model for ecosystem restoration}

\subsection{Background and structure of the conceptual model}

The EU Biodiversity strategy to 2020 has adopted a number of the Aichi Targets. To support the implementation of the Biodiversity strategy a number of working groups were established. One of these was the "Green Infrastructure and Restoration Prioritization Framework Working Group". As a part of its work the group suggested a conceptual 4level model of ecosystem restoration (Lammerant et al. 2014). This approach and the model have given useful input for our Nordic work, and our project offers an opportunity to go further, to explore how this model can apply in real situations and what the challenges are. During the project we have had a close contact with the EU working group and its secretary, and some of our project members participated in the EU working group. Below we give a short description of the model, based on the report from the working group (Lammerant et al. 2014). Then we list and discuss some principles and challenges addressed by the authors and discussed at the project workshop in March 2014 and at the SER 2014-conference in Oulu in August 2014.

The principle of the model is levels of degradation defined for all habitats, and it assumes that all land-cover of a given habitat can be allocated to one of these levels. A fundamental assumption of the model is that the levels must be defined in such a way that each level and changes between levels are quantifiable. Restoration of degraded land is then any climbing between the levels into a less degraded state (as defined for each habitat). The ecosystem types used in the model come from the standards defined by the project MAES (Mapping and Assessment of Ecosystem Services in Europe). ${ }^{4}$

The model takes a pragmatic approach built on the two guiding principles that restoration is a process, and that restoration requires modifi-

${ }^{4}$ http://biodiversity.europa.eu/ecosystem-assessments/european-level 
cation of abiotic and/or biotic factors. The model allows for small steps of progress, and takes into account that baselines vary much between habitats and countries. However, this assumes that the process of restoration must be well defined, so that levels of restoration can be identified and the transition between levels are measurable (Lammerant et al. 2014). The model divides ecosystem conditions into four distinct levels from poor (level 4) to excellent (level 1). Conceptually, each level is specified by sets of ecosystem descriptors and associated threshold values for each ecosystem type (see Figure 3.1). The descriptors can be very different in content, relevance and precision, and can be separated into state descriptors (information about the state for species, processes and abiotic conditions), pressure descriptors (data about threats and ecosystem degradation) and measure descriptors (can be used to indicate actions and initiatives at an early stage, before any ecological or social output can be documented). 
Figure 3.1: An illustrative example of the 4-level approach to ecosystem restoration suggested by the EU-working group. (Lammerant et al. 2014)

\begin{tabular}{|c|c|c|c|c|c|c|}
\hline & $\begin{array}{l}\text { ILLUS } \\
\text { AREA }\end{array}$ & TIVE EXAMPLE FOR A MEN & BER STATE WITH & IIGH CC & /ERAGE O & NATURAL \\
\hline & & & Types of areas & $\begin{array}{l}\text { Base- } \\
\text { line }\end{array}$ & $\begin{array}{l}\text { By } 2020 \\
\text { (and net } \\
\text { gain) }\end{array}$ & By 2050 \\
\hline $\begin{array}{r}\mathrm{E} \\
\mathrm{S}\end{array}$ & LEVEL 1 & $\begin{array}{l}\text { Satisfactory abiotic conditions. Key } \\
\text { species, properties and processes } \\
\text { of ecosystem patches and their } \\
\text { functions, at site level and at } \\
\text { landscape level, are in good to } \\
\text { excellent condition. }\end{array}$ & $\begin{array}{l}\text { a.o. 'wilderness' } \\
\text { areas and N2000 } \\
\text { habitats and species } \\
\text { in FCS, rivers and } \\
\text { lakes in good } \\
\text { ecological status } \\
\text { (GES), marine } \\
\text { ecosystems in GES, .... }\end{array}$ & $30 \%$ & $\begin{array}{l}32 \%(+2 \% \\
\text { from } L 2)\end{array}$ & $\begin{array}{l}40 \%(+8 \% \\
\text { from L2) }\end{array}$ \\
\hline T & LEVEL 2 & $\begin{array}{l}\text { Satisfactory abiotic conditions, } \\
\text { some disrupted ecological } \\
\text { processes and functions, either at } \\
\text { site level or at landscape level or at } \\
\text { both levels. Reduced or declining } \\
\text { diversity and key species, } \\
\text { compared to L1 but retains stable } \\
\text { populations of some native } \\
\text { species. }\end{array}$ & $\begin{array}{l}\text { a.o. N2000 habitats } \\
\text { and species not in } \\
\text { FCS, ... }\end{array}$ & $15 \%$ & $\begin{array}{l}28 \%(+15 \% \\
\text { from } L 3 ;- \\
2 \% \text { to } L 1)\end{array}$ & $\begin{array}{l}35 \%(+15 \% \\
\text { from } L 3 ;-8 \% \\
\text { to } L 1)\end{array}$ \\
\hline & LEVEL 3 & $\begin{array}{l}\text { Highly modified abiotic conditions, } \\
\text { many disrupted ecological } \\
\text { processes and functions, either at } \\
\text { site level or at landscape level or at } \\
\text { both levels. Dominated by artificial } \\
\text { habitats but retains some native } \\
\text { species and stable populations. }\end{array}$ & $\begin{array}{l}\text { a.o. non-protected } \\
\text { rural areas, not } \\
\text { including intensive } \\
\text { agriculture }\end{array}$ & $30 \%$ & $\begin{array}{l}16 \%(+1 \% \\
\text { from } L 4 ;- \\
15 \% \text { to } L 2)\end{array}$ & $\begin{array}{l}10 \%(+9 \% \\
\text { from } L 4 ;- \\
15 \% \text { to } L 3)\end{array}$ \\
\hline & LEVEL 4 & $\begin{array}{l}\text { Highly modified abiotic conditions, } \\
\text { severely reduced ecological } \\
\text { processes and functions, both at } \\
\text { site level and at landscape level. } \\
\text { Dominated by artificial habitats } \\
\text { with few and/or declining } \\
\text { populations of native species; } \\
\text { traces of original ecosystem hardly } \\
\text { visible. }\end{array}$ & $\begin{array}{l}\text { 'heavily modified } \\
\text { ecosystems' (e.g. } \\
\text { Intensive agriculture, } \\
\text { build urban areas, } \\
\text { roads, airports, } \\
\text { brownfield areas, } \\
\text { heavily modified } \\
\text { water bodies); } \\
\text { heavily degraded } \\
\text { 'natural' and 'semi- } \\
\text { natural' ecosystems }\end{array}$ & $25 \%$ & $24 \%$ & $15 \%$ \\
\hline & \multicolumn{3}{|c|}{ TOTAL SURFACE } & $100 \%$ & & \\
\hline & \multicolumn{3}{|c|}{ TOTAL ‘RESTORABLE’ SURFACE } & $70 \%$ & & \\
\hline & \multicolumn{3}{|c|}{$\begin{array}{l}\text { TOTAL 'RESTORED' SURFACE (cumulative starting } \\
\text { from baseline, and calculated on the basis of } \\
\text { 'restorable surface') }\end{array}$} & & $25.7 \%$ & $71.4 \%$ \\
\hline
\end{tabular}

For certain ecosystem types, like urban areas and other "transformed ecosystems" (in level 4), the objective is not necessarily to restore a location to its original, natural conditions. The project underpinned that the model is pragmatic and that decisions on levels, threshold values and descriptors have to be decided and defined at some stage. There must be 
a balance between scientific accuracy and efficiency, or "don't let the perfect be the enemy of the good" (Lammerant pers. comm.).

The working group has completed its work and it is currently up to the EU countries to take the work with national "Restoration Prioritization Frameworks" further. Due to large variations in habitat types and degradation status it is suggested that descriptors and threshold should be defined by the member states, but they should be encouraged to make some common standards for the same habitats (Lammerant et al. 2014). The present Nordic project has a potential for further progress on the issue for the Nordic countries (inside and outside the EU) and hopes to address and discuss some of the challenges and considerations that may be useful and relevant both for these countries and other EU countries.

\subsection{Assumptions and challenges for taking the model further}

\subsubsection{How to set the baseline and reference point?}

The EU 4-level model has defined a baseline/reference point as a fixed point in time to which progress towards the $15 \%$ restoration target can be measured (Lammerant et al. 2014). The time is set to 2010 because the EU Biodiversity Strategy was initiated then. Any progress should then be measured against the 2010-status of degraded land. Some consequences of this will be discussed later in this report.

In the 4-level model all areas in level 1 are considered as "not restorable land" because they are in no need for further climbing up the ladder. This implies that large part of land-area in level 1 will make it easier for a country to achieve the $15 \%$ as the denominator in the calculation is smaller. All areas in level 2, 3 and 4 are restorable land, and in the scope for restoration to achieve the $15 \%$ target. Consequently, for the calculations itself the threshold values (for the descriptors) between level 1 and 2 are essential for measuring progress, and also of political relevance. The "ideal" for progress of all land is level 1 (also defined as the reference point). The target for specific habitats, single projects or even at the country scale can be the reference point, but might also be other targets. For areas with a long history of degradation the target of restoring a pristine stage can give completely unrealistic expectations (Hobbs et al. 2011). And for some areas level 1 may not be a relevant or even wanted stage. For areas in level 4 (and perhaps 3) any progress up the ladder will contribute to less degraded land, and they might have a wanted (for 
society) future land-use that is not in accordance with standards in level 1 (or 2). Restored river course in cities is one example of this, supporting a number of species and nature values, but not meandering or holding original flooding schemes (Figure 3.2). Within the frame it should be obvious that setting the targets must be a key-action for individual restoration projects from local up to national scale.

Figure 3.2: Urban river restoration project aiming at restoring freshwater habitat and migrating wildlife between habitats along the river course

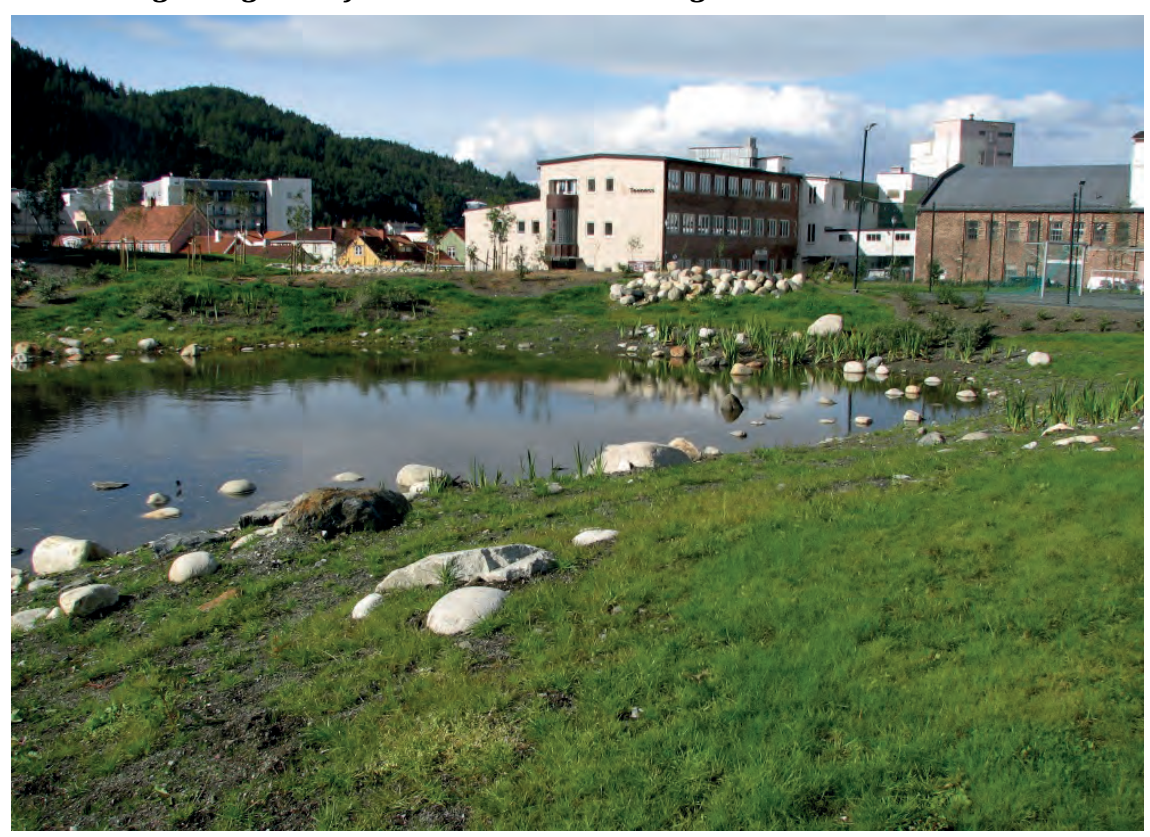

Photo: Dagmar Hagen.

\subsubsection{How to define descriptors and threshold values?}

The countries need to reach a common understanding of how to define and measure the level and status for different ecosystems, ideally an agreed list of descriptors and common understanding of the transitions between each level. This will include both a shared understanding of degraded state and measures of progress in restoration. This has been addressed as essential for further development and practical use of the 4-level model.

Existing descriptors from the two EU "nature directives" - the Birds Directive and the Habitats Directive, and other legislation such as the Water Framework Directive (WFD) and the Marine Strategy Framework Directive are supposed to cover the basic needs for some habitats. Some 
descriptors for "favorable Conservation status", as well as a clear 'improvement target' in target 1 of the EU BD strategy is implemented, but it is far from clear which role restoration should play. For the aquatic directives, there are more legally binding improvement targets, and these also cover restoration measures. The use of these have started, but it is still a bit too early to conclude how it works for measuring progress of restoration, but the descriptors from WFD should be very relevant as a model for terrestrial habitat for describing levels of degradation and also defining threshold values between them.

The EU-model prefers state descriptors to demonstrate progress, in particular biotic state descriptors. Pressure descriptors can support and assist the state descriptors as they indicate the trend of external influence. Measure descriptors can be useful to say something about positive trends, in particular in situations when the outcome (or progress in state descriptors) is slow. However, maintenance (like absence of further disturbance) is not a valid descriptor in the EU-model since maintenance is not a restoration measure (Lammerant et al. 2014). This calls for a clear definition of passive restoration. "Absence of further disturbance" can be a clear descriptor if passive restoration allows for natural processes of recovery without doing any interventions (= terminate the pressure) in disturbed areas. Examples are ditches that become overgrown and ending the drainage in wetlands or natural recovery in moderately disturbed heathland (Figure 3.3). Maintenance of undisturbed areas is definitely not a contribution, however essential to counteract any further loss of degraded land. 
Figure 3.3: Passive restoration by terminating pressure and allow for overgrowing of ditches in Estonia

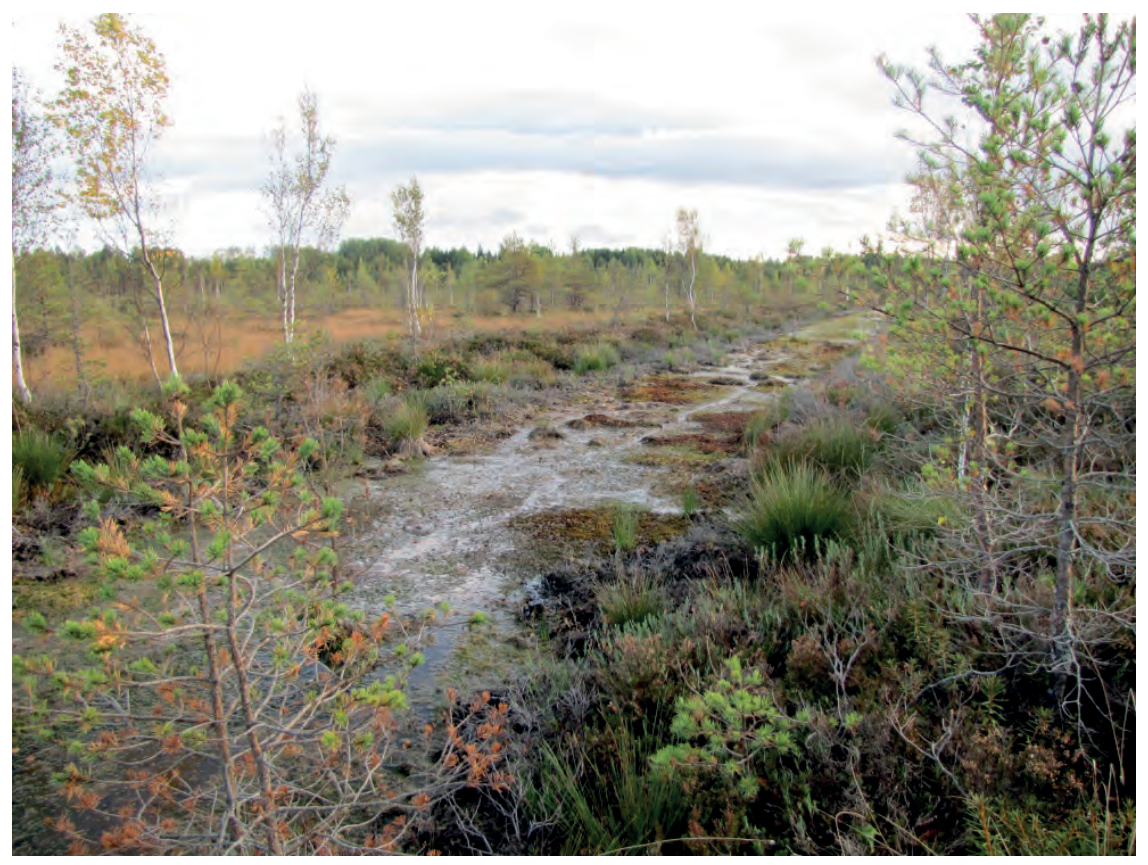

Photo: Margit Tennokene. 



\section{Degraded land}

\subsection{The concept of degradation and degraded land}

Eco-physical and social consequences of land degradation have been well documented and the cost of land degradation is a global issue, due to loss of biodiversity, damage to health and welfare of people, reduction of ecosystem services, and reduction of resilience to climate change (MEA 2005, TEEB 2010). In MEA and other initiatives the focus has often been on desertification in dry regions and areas in the tropics, far from the Nordic countries. Degraded land is however indeed also present in the Nordic region and concern have risen during the last decades as increased pressures on nature values and biodiversity have been documented in most ecosystems, although at different levels and intensities (Halldórsson et al. 2012, Normander et al. 2012). The dramatic example of erosion and land degradation, caused by overgrazing and deforestation on Icelandic volcanic soils is the most striking example in the Nordic (Figure 4.1). On the other hand, the abandonment of traditional mowing and grazing practices in the other Nordic countries during the last century has resulted in severe losses of semi-natural grasslands and their associated species. Today, agriculture, forestry, infrastructure development, invasive species, overgrazing, tourism and urbanization put pressure on all habitat types in the Nordic countries (Hagen et al. 2013) and Estonia (Estonian Ministry of Environment). A changing climate with increasing risks for natural hazards like flooding and landslides may increase the extent of degraded land (Schiermeier 2011). 
Figure 4.1: Severely degraded land in SW Iceland due to overgrazing and wind erosion under harsh climatic conditions on vulnerable volcanic soil

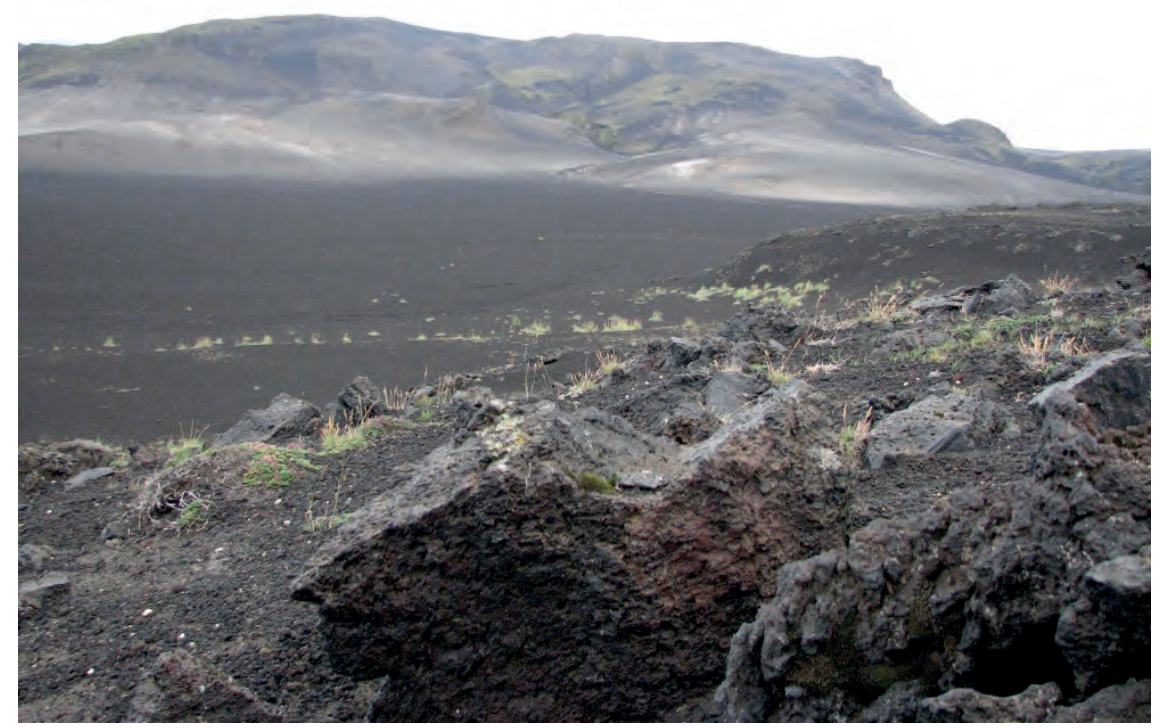

Photo: Dagmar Hagen.

Different levels of degradation as described in the 4-level model have not yet been defined in the Nordic countries. This approach on degraded land may be of interest for future management in the region. There is however a need to clarify the concept and relate it to Nordic conditions to see the full potential of the approach. The term "degraded land" is quite broad and used in different ways between actors, systems and topics. The same situation (or state) can even be viewed differently as one group regards it as degraded while others may consider the same situation as a good and beneficial state. Thus, a comparison of degraded states between areas and over time calls for well documented and commonly understood definitions of degraded state in specific cases. For our purpose we discuss the term degraded related to the state and future management of land.

There seems to be two lines of definitions, one focusing on the reduced ability of the land for production of goods and services, and the other with more focus on the function and capacity of natural ecosystem recovery. The FAO definition works as an example of the former: 
"the reduction in the capacity of the land to provide ecosystem goods and services and assure its functions over a period of time for the beneficiaries of these" ${ }^{5}$ whereas the IUCN definition ${ }^{6}$ illustrates the latter: "disturbances that are too frequent or severe to allow natural ecosystem recovery in a relevant or "reasonable" period of time". The Society of Ecological Restoration (2004) uses a series of related terms that actually incorporate the level of severity: from degraded (reduced ecological integrity and health), to damaged (acute and obvious changes) and destroyed (severe degradation where the physical environment also is changed).

In the EU WFD the status for degraded land has been defined and implemented. The WFD operates a five level system for ecological status (high, good, moderate, poor and bad). ${ }^{7}$ The reference state and the target are "good ecological status" and any status poorer that this calls for action.

Many "semi-natural" habitats in Europe and Scandinavia are shaped by human use. Today these areas are considered as semi-natural and dependent on continuous management by grazing, mowing and management of trees and shrubs to maintain their landscape-, cultural and biodiversity values. Restoration of these habitats requires a certain disturbance regime to be maintained, and the goal for restoration of such habitat is not a "natural" state, but conservation of a stable and wanted state by management with continuous interventions such as grazing or mowing (Figure 4.2).

\footnotetext{
${ }^{5} \mathrm{http}: / /$ www.fao.org/nr/land/degradation/en/

${ }^{6} \mathrm{https}$ //portals.iucn.org/blog/2013/01/08/defining-degraded-lands-for-sustainable-biofuels-and-beyond/

$7 \mathrm{http}$ ///ec.europa.eu/environment/water/water-framework/index_en.html
} 


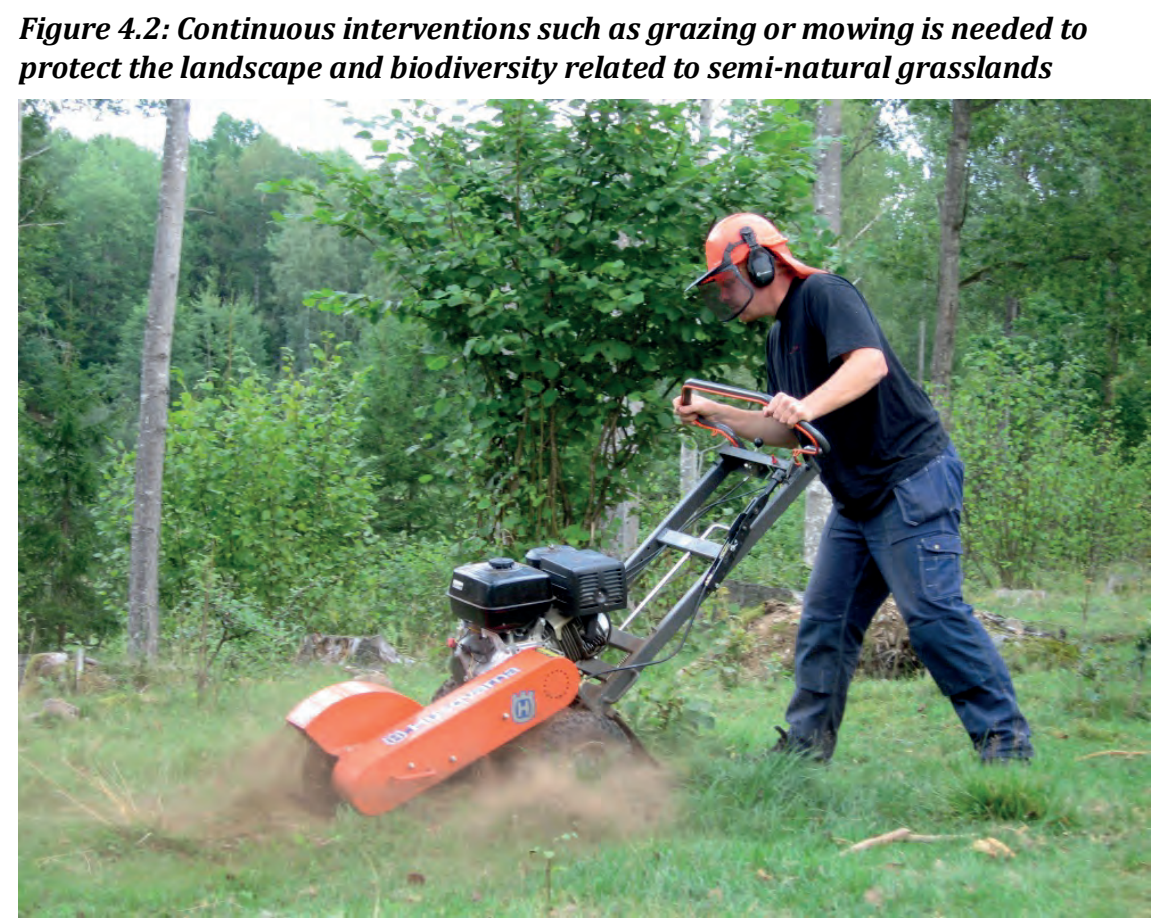

Photo: Anna Lindhagen.

\subsection{Degraded land in the Nordic countries and Estonia}

We have made an attempt to adopt the 4-level model for degradation of Nordic habitats. Our first challenge was to look for existing stages that might resemble the four levels of the model. Existing statistics were assessed for suitability and data needs were identified. All countries have some existing statistics describing status of different ecosystem types (Table 4.1) and this can to some degree be "translated" to the occurrence of degraded land. But the data differ in details and relevance for defining degradation levels. Freshwater systems were not included in our work as they are considered within the WFD. Urban areas were not included in this project, hence disturbance levels are not considered for this habitat type. 
Table 4.1: A summary of existing databases and statistics addressing land cover and may be used to assess the status of degraded land in the Nordic countries and Estonia. Fo some countries and habitats this guides directly to defined levels of degradation, but not for all and not consistently

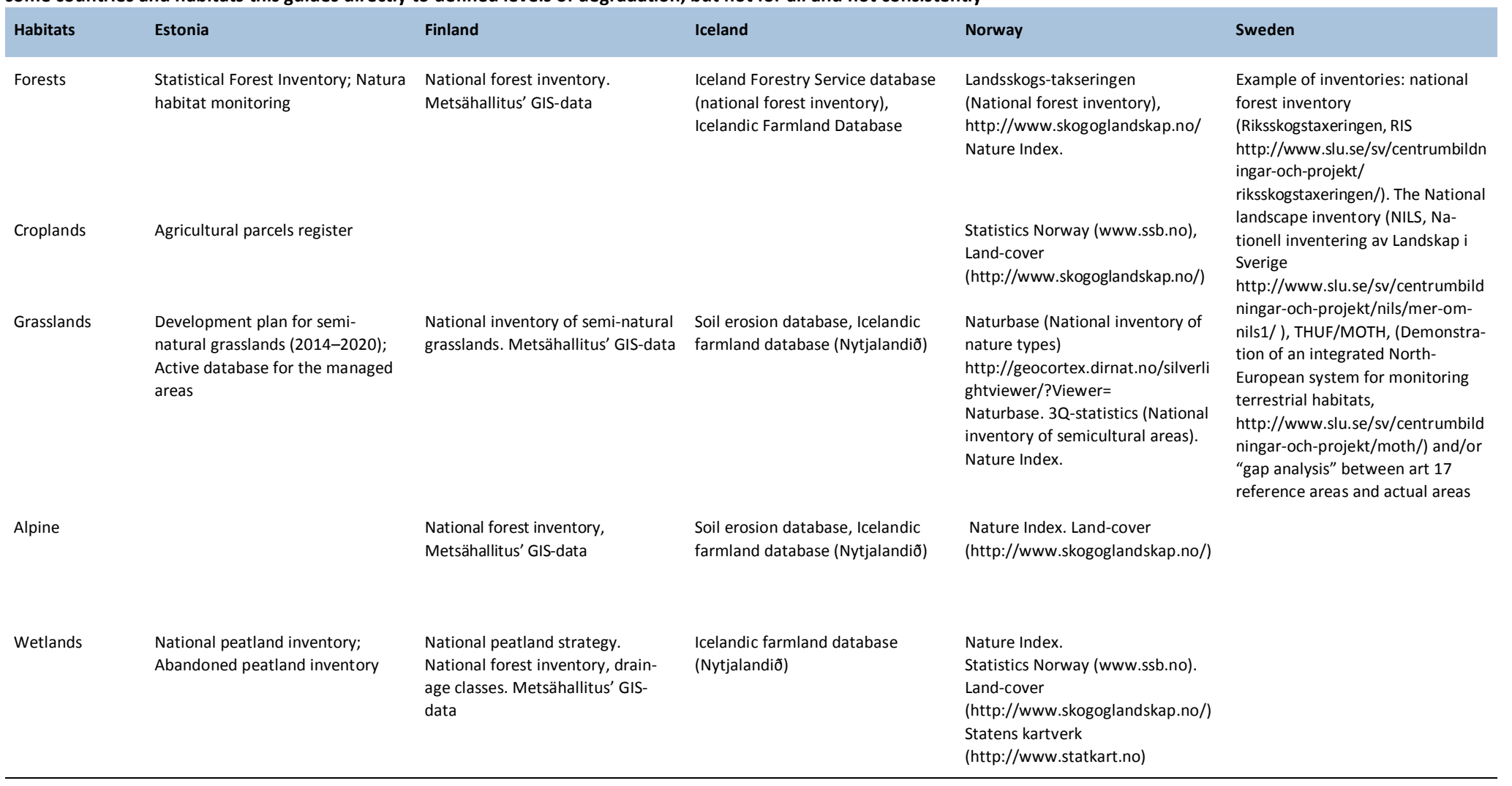


The current work shows that the countries have different traditions and approaches in considering levels of degradation. For some countries and habitats these can directly be used for defining levels of degradation in the EU 4-level model. Finland and partly Estonia have used this approach and have implemented it in management, but this is now abandoned for Finland (see below and chapter 6.2). Remaining countries have not done so, but Norway and Iceland seem to have systems that can be adopted or transformed into the 4-level model. The Nature Index may be used for the Norwegian habitats (Skarpaas et al. 2012), while for Iceland the classification of eroded land (Arnalds et al. 2001) and some inventories can be used together with experts' knowledge.

For countries with an established or a suggested definition of levels the definitions and transitions between levels are in general treated quite similar for each habitat. The most consistent is forest, where the levels are defined more or less along the gradient from pristine (level 1), moderately managed forest (level 2), intensively managed forest (level 3 ), forest areas where also abiotic factors are disturbed (level 4). However, the thresholds and descriptors used to define the stages differ, and are likely to relate to available statistics in each country. And as long as there is no leveling between countries the definition of thresholds will most likely vary between countries.

Denmark was not represented in the project group and no additional data have been collected for Denmark.

Estonia has used data from different sources including expert opinion to calculate levels for all ecosystem types, and has not developed a specific system for setting levels of degradation. The intention has been to set easily monitored targets/tasks. For forests the protection regimes have constituted the basis for defining the levels. For cropland and seminatural habitats the levels are defined according to the actual management methods. For wetlands protection regime together with implemented and planned restoration activities were used to define the levels, and levels from WFD were used for freshwater. These levels are implemented in management policy when restoration actions are included in action plans (Nature conservation development plan, Action plan for semi-natural habitats, Management plans for protected areas etc.).

Finland started to define degradation levels in 2013 based on the descriptions in the 4-level model. The data were mainly collected from the National Forest Inventory database (NAFI) but also several other sources were used. However, when Finland started the 15\% restoration prioritization project in the beginning of the year 2014, the four degradation levels were abandoned. Finland then decided to use continuous 
variables of degradation instead of four categories, and this new approach was called the "Ten step model" (ELITE-model in Finnish). This model is briefly described in chapter 6 .

Iceland has not yet defined degradation levels within habitats that can directly be assigned to the 4-level model. An erosion classification system, the AUI Farmland Database (Nytjaland), 8 the Iceland Forestry Service database and expert knowledge were used for a first attempt to propose a degradation classification for habitats to this project. An erosion classification system was developed in the 1990s and all land assigned to six classes (Arnalds et al. 2001). These were no erosion (0), little erosion (1), slight erosion (2), considerable erosion (3), severe erosion (4) and extremely severe erosion (5). The erosion mapping showed that over $50 \%$ of the island had considerable to extremely severe erosion (Arnalds et al. 2001). The classification of land based on erosion give good estimates on conditions of land, and can also be an indication of degradation (Figure 4.3). This is however not fully adequate for degradation classification as land classified as 1 and 2 could be degraded although well vegetated, and some land is eroded due to natural reasons. The erosion classification was regarded applicable for grassland and alpine areas, and the three first levels correspond to erosion classes 0,1 and 2, while level 4 contains classes 3-5. Further work is needed for improvement of the first three levels in particular if the 4level model approach would be adapted in Iceland. Expert knowledge and classifications developed in the Icelandic farmland and Iceland Forestry Service databases were used to obtain suggested classification for forests and wetlands in Iceland. The AUI Farmland Database project contains a surface classification based on satellite images. Ten vegetation classes that reflected grazing values and could be detected by remote sensing techniques, were defined (Arnalds \& Barkarson 2003). These are wetland, "half-bog" woodland, grassland, rich heath, poor heath, moss, half vegetated, desert and cultivated.

${ }^{8} \mathrm{http}: / /$ groa.rala.is/kortavefsja/default.aspx 
Figure 4.3: In Iceland the status of erosion can be used as a basis for classification of degraded land

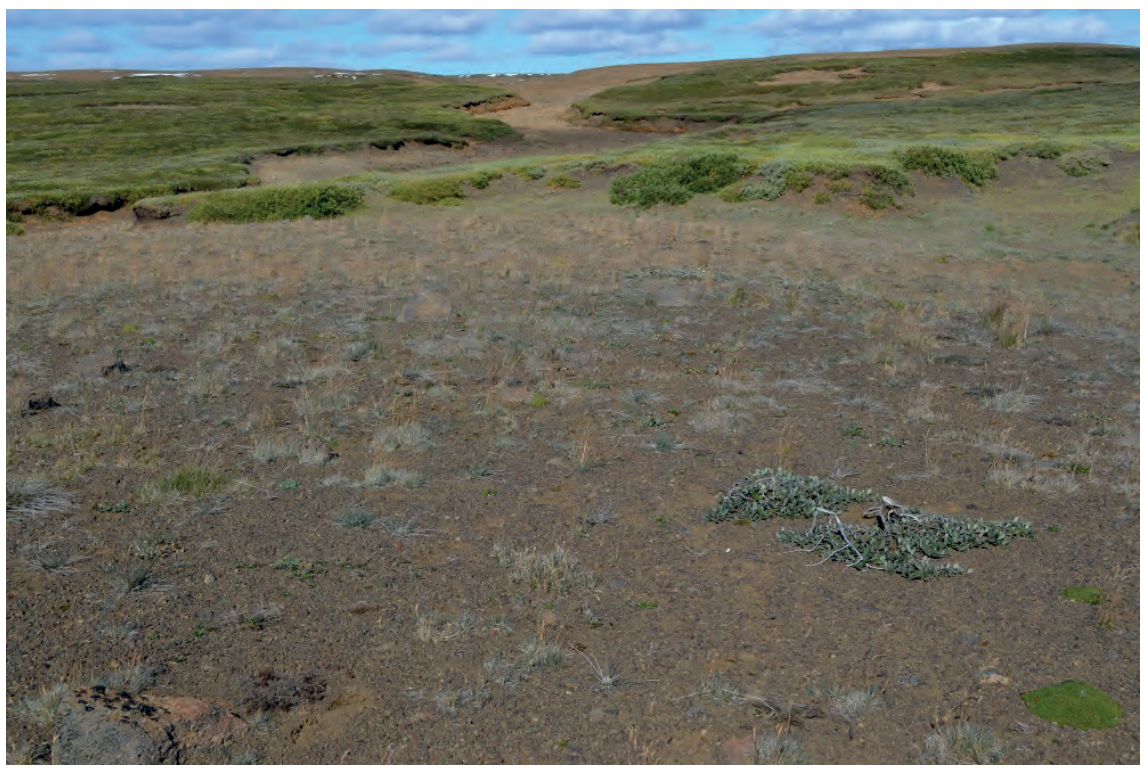

Photo: Kristín Svavarsdóttir.

Norway has not set the specific four level of degradation for the different habitat types. However, at least two existing systems are relevant for the description of status, and might also be useful as a basis for calculating progress of restoration if further developed. A system for calculating the state of condition is integrated into "Naturtyper i Norge". ${ }^{9}$ In this system a number of relevant disturbance factors and appurtenant variables have been defined. All variables have a number of levels defined by a "state index" (the description of the system is only available in Norwegian). ${ }^{9}$ These states indices can most likely also work as threshold values between disturbance levels, but so far this has not been a specified objective for this system and no statistics are available for degraded land in this system. Theoretically such stages/levels can be mapped on any scale and further used to calculate progress of restoration, but this requires large resources and most likely only relevant for specific purposes (like for specific nature types, restricted geographic areas or specific restoration priorities). The "Nature Index" (NI) is a different approach to describe levels of disturbance (Nybø et al. 2011, Skarpaas et al. 2012). The

${ }^{9}$ http://www.naturtyper.artsdatabanken.no/ 
$\mathrm{NI}$ is an aggregated measure put together from more than 300 biodiversity indicators to reflect the state of terrestrial and marine ecosystems. The Nature Index provides statistics on degradation on national and county level, ranging from 1 to 0 ( 1 means that the indicator is in the reference state, whereas 0 indicates a seriously degraded state). The Ministry of Climate and Environment currently works on developing further the national parameters in "Environmental Status of Norway". Some initial discussions on relevant approaches for applying the 4- level model in Norway have taken place, and one method that has been proposed is to see if levels of degraded state (cf. the 4-level model) can directly relate to the Nature Index. Suggested levels are $1 . \mathrm{NI}=0,75-1 ; 2$. $\mathrm{NI}=0,5-0,74 ; 3 . \mathrm{NI}=0,25-0,49 ; 4 . \mathrm{NI}=0-0,24$.

In Sweden, there are several inventories that describe the status for biodiversity in different habitats, but none of these address degradation or restoration needs specifically. The parameters that are described in the inventories, can however probably be used to identify degradation/restoration needs at least roughly. For semi-natural grasslands, a national inventory was carried out in 2004-2005 (ängs- och betesmarksinventeringen). ${ }^{10}$ It describes the status of the studied grasslands, including overgrowth, nitrification or negative disturbance, and has a special category for grasslands that need restoration. For wetlands, the national wetland inventory (våtmarksinventeringen) ${ }^{11}$ covers some parameters that can be related to restoration needs, such as the presence of drainage and overgrowth. The national forest inventory (Riksskogstaxeringen, RIS $)^{12}$ presents an overall image of the status of forests in Sweden. The level of dead-wood, presence of old trees or old-growth stands, or forests influenced by drainage, are parameters that could be used to identify restoration needs on a national level. For freshwater habitats, a national strategy for the restoration of streams and rivers was published in 2007.13 For protected areas, a national monitoring scheme has been developed that could be used for identifying restoration needs. Restoration needs are also often covered by the site's management plans, but there is no national summary of these data. For forests and wooded areas in protected areas, Naturvårdsverket has devel-

\footnotetext{
10 http://www.jordbruksverket.se/amnesomraden/miljoklimat/ettriktodlingslandskap/ angsochbetesmarksinventering.4.207049b811dd8a513dc80003958.html

${ }^{11} \mathrm{http} / /$ www.naturvardsverket.se/Documents/publikationer/978-91-620-5925-5.pdf

12 http://www.slu.se/sv/centrumbildningar-och-projekt/riksskogstaxeringen/

13 http://www.naturvardsverket.se/Documents/publikationer/620-5746-4.pdf
} 
oped management priorities that also cover restoration activities. In 2013 Sweden reported on the status of habitats and species under the Habitat directive (according to article 17 of the Directive), and birds under the EU Birds directive (according to article 12). These reports can be used to show gaps between the current status of species or habitats (population levels, current area etc.), and the reference values that describe what would be needed for a "favorable" conservation status - i.e. that they also can be used to identify restoration needs. 
Table 4.2: Levels of degraded land in the Nordic countries and Estonia. For Finland and Estonia the levels have been defined and approved. For Iceland and Norway the levels have not been defined. For Iceland suggested levels are elaborated based on soil erosion, forest, land-use statistics and expert judgments. The Norwegian levels are based on initial discussions where a 4-level approach is applied through the use of the Nature Index. Note that Finland has left the four level approach in the restoration prioritization framework and now use continuous variables to describe degradation (see chapter 6)

\begin{tabular}{|c|c|c|c|c|c|}
\hline Habitats & Estonia & Finland & Iceland & Norway & Sweden \\
\hline Forest 1 & pristine (under strict protection) & pristine & $\begin{array}{l}\text { limited impact ("old" ungrazed } \\
\text { forest remnants) }\end{array}$ & $\begin{array}{l}\text { good state: Protected areas and old } \\
\text { forest }\end{array}$ & no levels defined \\
\hline Forest 2 & moderately managed forest & moderately managed forest & $\begin{array}{l}\text { moderately managed forests } \\
\text { (mainly managed by the Iceland } \\
\text { Forestry Service) }\end{array}$ & $\begin{array}{l}\text { moderately managed forests } \\
\text { (productive forest areas with some } \\
\text { selective felling) }\end{array}$ & no levels defined \\
\hline Forest 3 & intensively managed forest & intensively managed forest & disturbed (often grazed) forests & $\begin{array}{l}\text { intensively managed forests (forest } \\
\text { management by stands) }\end{array}$ & no levels defined \\
\hline Forest 4 & abiotic factors disturbed & also abiotic factors disturbed & $\begin{array}{l}\text { badly disturbed - none or few } \\
\text { resembles of birch woodland }\end{array}$ & $\begin{array}{l}\text { former forest areas with new land } \\
\text { use (like infrastructure, industry) }\end{array}$ & no levels defined \\
\hline Cropland 1 & do not exsist & no levels defined & not applicable & no levels defined & no levels defined \\
\hline Cropland 2 & croplands under 15ha; & no levels defined & not applicable & no levels defined & no levels defined \\
\hline Cropland 3 & $\begin{array}{l}\text { croplands that receive Environmen- } \\
\text { tal Friendly management subsidy }\end{array}$ & no levels defined & not applicable & no levels defined & no levels defined \\
\hline Cropland 4 & heavily managed croplands & no levels defined & not applicable & no levels defined & no levels defined \\
\hline Grassland 1 & pristine & $\begin{array}{l}\text { high values and continuous man- } \\
\text { agement }\end{array}$ & $\begin{array}{l}\text { good evological conditions (no } \\
\text { erosion) }\end{array}$ & $\begin{array}{l}\text { protected and/or regularly man- } \\
\text { aged areas }\end{array}$ & no levels defined \\
\hline Grasland 2 & $\begin{array}{l}\text { areas managed trough Single Area } \\
\text { Payment (management may not be } \\
\text { satisfactory) }\end{array}$ & $\begin{array}{l}\text { quite high values, but not satisfac- } \\
\text { tory management }\end{array}$ & $\begin{array}{l}\text { valuable areas without satisfactory } \\
\text { management (little erosion) }\end{array}$ & $\begin{array}{l}\text { valuable areas without satisfactory } \\
\text { management }\end{array}$ & no levels defined \\
\hline Grassland 3 & $\begin{array}{l}\text { areas that have not been managed } \\
5-10 \text { years }\end{array}$ & $\begin{array}{l}\text { reduced values and management } \\
\text { needs to be started, }\end{array}$ & $\begin{array}{l}\text { degraded with detoriated structure } \\
\text { and function (some erosion) }\end{array}$ & $\begin{array}{l}\text { reduced value, but can be restored } \\
\text { by starting management (no } \\
\text { statistics available) }\end{array}$ & no levels defined \\
\hline Grasland 4 & $\begin{array}{l}\text { areas that have not been managed } \\
\text { over } 10 \text { years. }\end{array}$ & $\begin{array}{l}\text { restorable areas, overgrown but } \\
\text { potentially grassland in the long run }\end{array}$ & $\begin{array}{l}\text { badly degraded and non-functional } \\
\text { ecosystem (considerable/severe } \\
\text { erosion, sparsely vegetated) }\end{array}$ & $\begin{array}{l}\text { reduced values, can be improved by } \\
\text { restoration. }\end{array}$ & no levels defined \\
\hline Alpine 1 & no levels defined (not relevant) & no levels defined & $\begin{array}{l}\text { good ecological conditions (no } \\
\text { erosion) }\end{array}$ & no levels defined & no levels defined \\
\hline
\end{tabular}




\begin{tabular}{|c|c|c|c|c|c|}
\hline Habitats & Estonia & Finland & Iceland & Norway & Sweden \\
\hline Alpine 2 & no levels defined (not relevant) & no levels defined & $\begin{array}{l}\text { valuable areas without satisfactory } \\
\text { management (little erosion) }\end{array}$ & no levels defined & no levels defined \\
\hline Alpine 3 & no levels defined (not relevant) & no levels defined & $\begin{array}{l}\text { degraded with detoriated structure } \\
\text { and function (some erosion) }\end{array}$ & no levels defined & no levels defined \\
\hline Alpine 4 & no levels defined (not relevant) & no levels defined & $\begin{array}{l}\text { badly degraded and non-functional } \\
\text { ecosystem (considerable/severe } \\
\text { erosion, sparsely vegetated) }\end{array}$ & no levels defined & no levels defined \\
\hline Wetlands 1 & pristine and near pristine & pristine & $\begin{array}{l}\text { good ecological conditions (undi- } \\
\text { sturbed) }\end{array}$ & $\begin{array}{l}\text { good ecological conditions. Key } \\
\text { species and ecological function. }\end{array}$ & no levels defined \\
\hline Wetlands 2 & drainage influence & drained & $\begin{array}{l}\text { disturbed (fragmented, altered } \\
\text { hydrology) }\end{array}$ & $\begin{array}{l}\text { partly good ecological state, but } \\
\text { some low indicators }\end{array}$ & no levels defined \\
\hline Welands 3 & drained & $\begin{array}{l}\text { drained peatland without active } \\
\text { forestry use }\end{array}$ & drained without utilisation, & $\begin{array}{l}\text { poor to medium good ecological } \\
\text { state. Poor state for key species and } \\
\text { function }\end{array}$ & no levels defined \\
\hline Wetlands 4 & $\begin{array}{l}\text { peatmining areas (including aban- } \\
\text { doned areas) }\end{array}$ & abandoned peat harvesting field & drained with utilisation & $\begin{array}{l}\text { the ecosystem is completely } \\
\text { degraded and partly used for other } \\
\text { purposes. }\end{array}$ & no levels defined \\
\hline
\end{tabular}


Based on the available statistics and the defined or suggested levels in Table 4.2 it is possible to allocate numbers for some countries and habitats (Table 4.3). These numbers are based on different statistics and different definitions of degraded levels for the countries, and partly done as an exercise for this project. Consequently these number cannot be adopted as the true current status within the countries, and also have limited value for comparing between countries. However, the status overview reveals that if wanted and given priority, this can be further developed and perhaps standardized for the purpose. The need for additional data to support the existing databases will be demonstrated during this work.

Table 4.3: The status for degraded land (\%) in the Nordic countries and Estonia, divided into four levels as suggested in the EU 4-level model

\begin{tabular}{|c|c|c|c|c|c|}
\hline Habitats & Estonia & Finland & Iceland & Norway & Sweden \\
\hline Forest 1 & 9 & 26 & $\begin{array}{r}\text { Data partly } \\
\text { available, but } \\
\text { much work } \\
\text { needed for a } \\
\text { rough estimate }\end{array}$ & 8 & \\
\hline Forest 2 & 16 & 74 & As above & 46 & \\
\hline Forest 3 & 75 & 0.07 & As above & 46 & \\
\hline Forest 4 & 0 & 0 & As above & 0 & \\
\hline Cropland 1 & 14 & & & & \\
\hline Cropland 2 & 16 & & & & \\
\hline Cropland 3 & 29 & & & & \\
\hline Cropland 4 & 41 & & & & \\
\hline Grassland 1 & 45 & & $\begin{array}{r}\text { Data partly } \\
\text { available, but } \\
\text { much work } \\
\text { needed for a } \\
\text { rough estimate }\end{array}$ & 0 & \\
\hline Grasland 2 & 5 & & As above & 24 & \\
\hline Grassland 2 & 30 & & As above & 72 & \\
\hline Grasland 3 & 20 & & As above & 4 & \\
\hline Alpine 1 & & & $\begin{array}{r}\text { Data partly } \\
\text { available, but } \\
\text { much work } \\
\text { needed for a } \\
\text { rough estimate }\end{array}$ & $\begin{array}{r}\text { Data available in } \\
\mathrm{NI} \text {, value not } \\
\text { calculated }\end{array}$ & \\
\hline Alpine 2 & & & As above & $\begin{array}{r}\text { Data available in } \\
\mathrm{NI} \text {, value not } \\
\text { calculated }\end{array}$ & \\
\hline
\end{tabular}




\begin{tabular}{|c|c|c|c|c|c|}
\hline Habitats & Estonia & Finland & Iceland & Norway & Sweden \\
\hline Alpine 3 & & & As above & $\begin{array}{r}\text { Data available in } \\
\mathrm{NI} \text {, value not } \\
\text { calculated }\end{array}$ & \\
\hline Alpine 4 & & & As above & $\begin{array}{r}\text { Data available in } \\
\mathrm{NI} \text {, value not } \\
\text { calculated }\end{array}$ & \\
\hline Wetlands 1 & 44 & 73 & $\begin{array}{r}\text { Data partly } \\
\text { available, but } \\
\text { much work } \\
\text { needed for a } \\
\text { rough estimate }\end{array}$ & 1.1 & \\
\hline Wetlands 2 & 20 & 0.01 & As above & 50.4 & \\
\hline Wetlands 3 & 24 & 15 & As above & 37.1 & \\
\hline Wetlands 4 & 12 & 11 & As above & 11.4 & \\
\hline Freshwater 1 & 1 & & & 18 & \\
\hline Freshwater 2 & 66 & & & 37 & \\
\hline Freshwater 3 & 28 & & & 25 & \\
\hline Freshwater 4 & 5 & & & 10 & \\
\hline Freshwater 5 & & & & 2 & \\
\hline
\end{tabular}

The data are reported based on the sources in Table 4.1, however it is important to stress that the data are not made for this purpose. The data for all countries are very preliminary, do not claim to be the "true" situation, but are relevant to illustrate the difficulties and challenges with defining degradation classes. The empty cells indicate that levels are not defined or statistics not available (Sweden has similar statistics as the other countries, but no levels defined). Freshwater habitats did not get attention in the EU-model because it is handled in the WFD, but are included here because relevant data are available.

\subsection{Considerations for the $15 \%$ target approach}

\subsubsection{Comparing levels and degraded state between countries}

We have, like the EU-report (Lammerant et al. 2014), given quite a lot of attention to degraded land. Defining levels of degradation can be the essential basis for working towards the $15 \%$ target if the 4 -level model is adapted, as the progress of restoration (= the reduction of degraded land) must be measured against a reference value. However, our work shows that such strong focus on degraded land can draw the focus away from what really matters: the implementation of restoration activities, and prioritization of the most important actions. 
Even within the Nordic countries natural conditions and land use history differ greatly, hence the same "stage" (e.g. in a forest) can be evaluated and ranked differently. This is mainly a problem when comparing between the countries, but might also have an influence on national priorities and initiatives as the total area assigned to level 1 set the standard for "restorable land". However, to be pragmatic and realistic, the $15 \%$ target is in fact unattainable within 2020 , so any initiative that would increase the restoration activity is a contribution.

Comparing levels and numbers between countries could be of interest for improving our knowledge and produce input for future strategies within and between countries. One challenge is that a specific nature type may be defined in different ways, so the same type of nature ends up in different categories in the different countries. Data on wetlands in Table 4.3 is a good example, as it is perhaps not likely that wetland in good conditions in Norway $(1.1 \%$ in level 1$)$ is so much worse than in Finland (73\% in level 1). This illustrates that the present datasets and definitions are unsuitable for a comparison between countries directly, but can be useful for helping countries realize the need for improved statistics and elaborating existing data. Furthermore this may highlight the need for each country to investigate better the background of available data and their relevance. The low number for level 1 for wetlands in Norway can be explained partly by the melting of permafrost due to climate change (an indicator in NI), and this cannot be reversed by applying ecological restoration.

\subsubsection{A net 15\% - new disturbed areas must be deducted from any progress}

The Aichi target 15 formulates a net level of restoration (15\% of degraded land). This implies that any new disturbed land during the same time period must be compensated or restored on top of the $15 \%$. This calls for a system to monitor or measure degradation, and not only to measure progress in restoration. A single intervention can cause a drop of several steps down the ladder in the EU 4-level model when intact nature areas (in level 1 and partly 2) are affected, thus the disturbed ecosystem would be classified as level 3 or 4 . This will have severe implications for the total calculation (Figure 4.4). 
Figure 4.4: Based on the EU 4-level model a progress in restoration of degraded land can be measured by climbing the ladder, step by step. Degradation of new land is shown in the opposite direction, dropping the ladder step by step or even a large drop from the top to the bottom at once

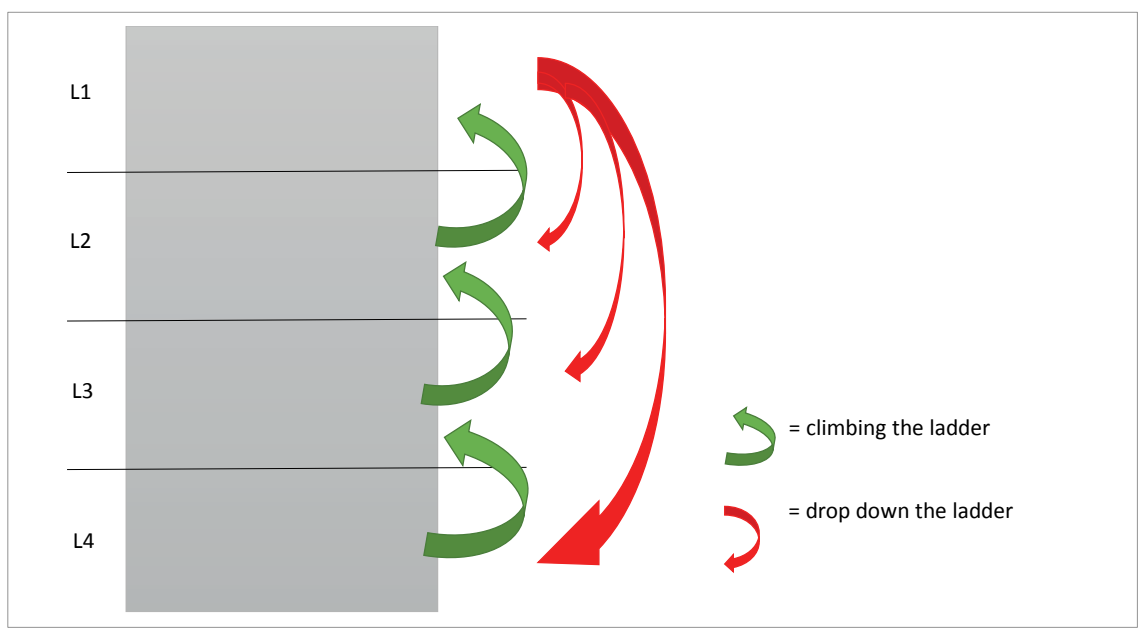

This is perhaps particularly relevant for the Nordic countries since relatively large areas are in the upper levels of the ladder. The matter of spatial scale must also be considered, as it is not obvious exactly how large areas that will be considered degraded when a new site is disturbed - only those directly influenced, or should bordering areas also be included since the disturbance increases the level of fragmentation (Figure 4.5). The importance of protecting and keeping intact nature areas (level 1) is thus essential for the Nordic countries in relation to the Aichi targets. 


\begin{abstract}
Figure 4.5: Development of renewable energy and related infrastructure, would move intact areas (level 1) to severely disturbed (level 4), hence dropping several steps. This contrasts restoration of degraded land as it must climb step by step (generally slow).This will have implications for the total net calculation of progress
\end{abstract}

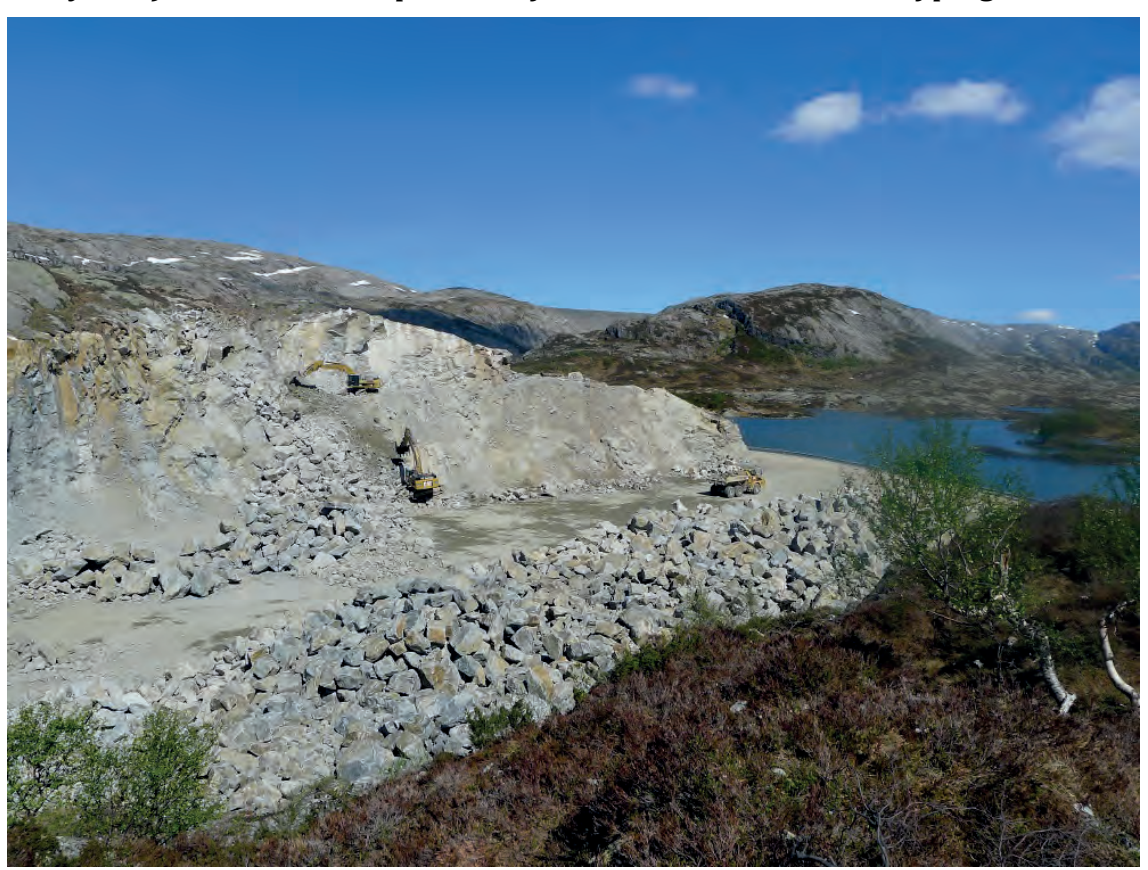

Photo: Dagmar Hagen.

\title{
4.3.3 Implications of using 2010 as a reference year
}

The EU-model has set 2010 as the baseline year for restoration. This means that all progress in restoration towards the $15 \%$ target should be measured against this year (or the closest year with available data).

In the Nordic countries and Estonia, as for the rest of Europe, large areas have been under pressure and degraded for a very long time. Partly these areas are at an alternative state (even a wanted alternative state) but can still be considered as degraded from its natural state. The need for restoration is related to what happened much longer time ago. In most of the countries the regrowth of semi-natural grasslands and heathland since the 1950-60s is a good example of this. Another example is the dramatic deforestation of Iceland during centuries leaving only small remnants of woodland in 2010. Hence, should the reference be the original 25-40 \% woodlands (Bjarnason 1974, Sigurdsson 1977) or the present 1\% (Traustason \& Snorrason 2008) be the base for the $15 \%$ restoration? All degraded areas not in a favorable condition in 2010 are restorable land. A 2010 baseline should then not imply reduced ambi- 
tions for restoration of "lost" habitats, like the semi-natural grasslands that were abandoned during the 20th century, if it can be shown that they were "missing" in 2010.

An alternative approach is to define a reference state based on ecological qualities of the descriptors or the ecological "potential" of the land. A reference area targeted for habitats/ecosystem and species each would then be the basis for formulating restoration targets. This approach is used for Nature Index in Norway in which a reference state is identified for each indicator individually reflecting an ecologically sustainable state (Certain et al. 2011). For the EU member states, the reference values in the nature directives could work as such targets. An ecologically defined reference state would perhaps give more focus on restoring nature values, and less on the calculations of percentages. The descriptors are fundamental for defining such reference states and further to elaborate threshold values between the levels in the model based on ecological attributes.

Natural hazards, like floods and volcanic activity are excluded from the 4-level model (Lammerant et al. 2014). Extreme conditions may contribute to lower resilience in ecosystems of the north, thus requiring more attention. The degradation history of Iceland after human arrival illustrates how new pressures brought by people on fragile ecosystems can have catastrophic impacts (Arnalds 1987). The removal of trees and introduction of grazing animals triggered degradation processes that lead to loss of birch woodlands (Aradottir \& Arnalds 2001) and vegetation cover (Thorsteinsson et al. 1971) and deserts developed (Arnalds et al. 2001). Thus ensuring resilience (see Suding 2011) may even be of more importance when restoring ecosystems in the north. 


\section{Restoration for the reduction of degraded land.}

Ecological restoration puts focus on repairing disturbed and degraded natural areas, species or ecosystems, and is defined by the Society for Ecological Restoration International (SER) as "the process of assisting the recovery of an ecosystem that has been degraded, damaged, or destroyed", relating the recovery to health, integrity and sustainability of ecosystems (SER 2004). This relates to the SER definition of degraded land (see chapter 4.1). Ecological theory and concepts are an important basis for restoration ecology (Palmer et al. 2004, Young et al. 2005), including biology, hydrology, soil sciences, landscape ecology. There is however, also a growing understanding that socioeconomic frameworks are needed for restoration projects to support the needs and acceptance in the society (SER 2004, Clewell \& Aronson 2013, Baker \& Eckerberg 2013). Lately there has also been an increased focus on restoration as a tool to recover goods and services provided by ecosystems (Clewell \& Aronson 2013).

A number of definitions and concepts (see box) are used to describe the activity of retaining wanted values/qualities following a disturbance. For the restoration of terrestrial habitats two main traditions can be defined, applied and ecological approaches (Aradottir \& Hagen 2013). The applied approach originates from the disciplines of agronomy, forestry, horticulture and technology, and focuses on practical solutions like cultivation methods, nutrient subsidies and availability of plant material, whereas the ecological approach focuses on restoration of ecological function and integrity and emphasizes the application of ecological principles (Bradshaw 1983, Whisenant 1999). Active restoration is often carried out as a combination of these two approaches. An integrated approach allows for a basis in ecological theory, and the tools used come from agronomy, forestry, horticulture, range science, microbiology, engineering and landscape architecture (Aradottir \& Hagen 2013). 
- Rehabilitation: reparation of ecosystem processes, productivity and services and less focus on species composition, community structure and function (SER, 2004).

- Reclamation is almost a synonym to rehabilitation, but with a broader meaning and including elements like productivity or esthetic value (Aronson et al. 1993, SER 2004, Whisenant 1999).

- Revegetation: establishment of vegetation cover (often the first step for further rehabilitation or restoration).

- Ecological engineering: the design of sustainable ecosystems that integrate human society with its natural environment for the benefit of both (Mitsch \& Jorgensen 2003).

- Ecological restoration: the process of assisting the recovery of an ecosystem that has been degraded, damaged, or destroyed (SER 2004).

- Restoration ecology: the science on which ecological restoration is based, normally considered a part of conservation biology.

Due to the general conditions in the Nordic countries more focus has been on the restoration of "pristine" conditions than countries further south in Europe. The exception is the semi-natural grasslands and wetlands where the cultural and management perspective are clear. In Finnish the term ecological restoration (=ennallistaminen) includes only non-recurring measures (e.g. controlled burning) and ecological management (=luonnonhoito) includes the repeated/recurring measures (e.g. grazing). In English the word ecological restoration is, at least partly, used for both. If the level of severely degraded land in a region or an ecosystem is low the focus for the restoration work often can be to achieve targets for the biological status of habitats and species. In severely degraded areas, such as abandoned industrial sites in growing cities, a more relevant focus for the restoration work can be to allocate new land-use, such as residential areas and related green infrastructure. An interesting aspect in Europe is the on-going discussion about the potential for "rewilding" even the cultural habitats, by introduction of wild ungulates and keeping human interference at a minimum. The (still) presence of wilderness in Nordic areas can be the reason why this discussion so far has not been on in the region. 


\subsection{Are all restoration activities relevant for the Aichi targets?}

The range of approaches and definitions reflects a large variation of goals for restoration. Recent emphases in some countries on restoration of ecosystem services have not only highlighted potential benefits of restoration but also revealed contradictions as restoration of a single service might be in conflict with biodiversity conservation (Bullock et al., 2011). Thus, the goal setting influences the type of restoration chosen and to what extend a given restoration project contributes to reaching the Aichi targets. Projects assist in achieving the targets as long as they in one way or the other contribute to climbing the ladder (cf. the 4-level model). However, different types of projects will contribute in different parts of the ladder (Figure 5.1). Technical rehabilitation projects, ecological engineering etc. most likely contribute in the "lower parts" of the ladder lifting status from level 4 to 3 , while projects focusing on restoring the ecological function for specific habitats or species may contribute all up to level 1. Rehabilitation projects applied in the upper part of the ladder can give negative impact on biodiversity and thus not contribute to the Aichi-goals, rather the opposite.

The four paradigms described by Suding (2011) may be a useful framework for categorizing restoration projects and formulating goals: (i) restoration to guide recovery of damaged ecosystems; (ii) restoration as a compensation for habitat loss; (iii) restoration to deliver ecosystem services, and (iv) restoration to ensure resilience. It is obvious that restoration projects in fact include a large diversity of goals and activities. Specific and clear goals are needed to evaluate progress and outcome of restoration, and the 4-level model state this in particular. However, at present the evaluation against clear goals is not the rule, but rather the exception in restoration projects (Nilsson et al., in prep.). Concluding about success (or failure) must be done closely related to the goal of the restoration and the preferred outcome (e.g. Zedler 2007). 
Figure 5.1: Different types of restoration / rehabilitation projects can contribute to different parts of the ladder in the EU 4-level model. An intervention can contribute to the Aichi target when used at the bottom of the ladder, but can work against the target if used in the upper part

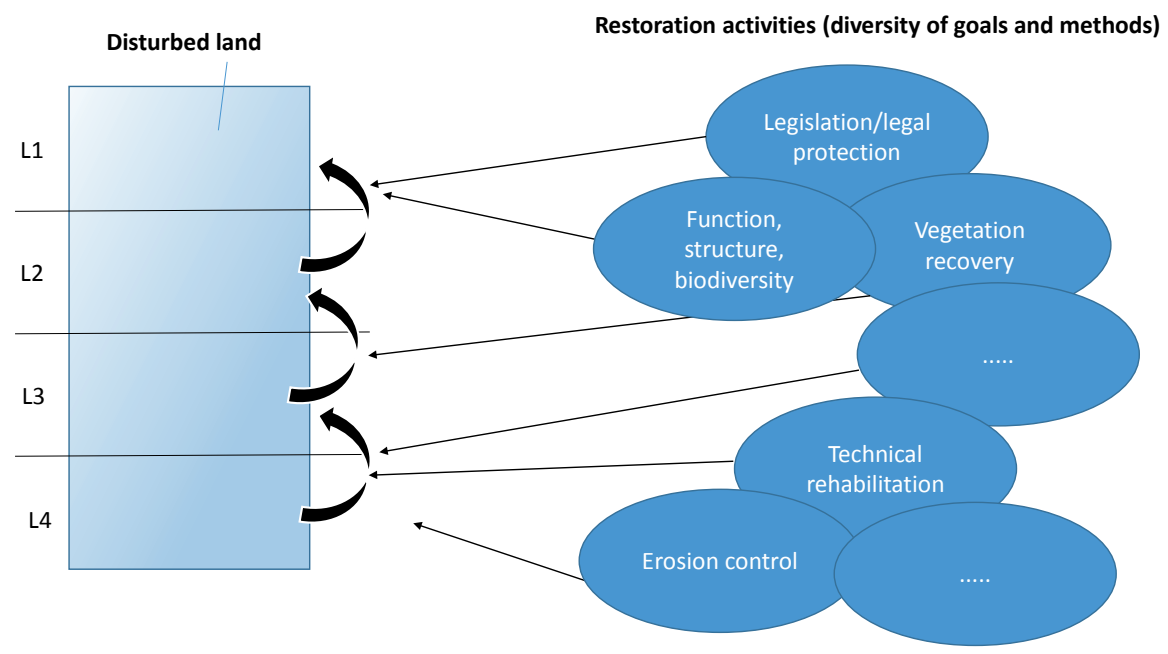

There have been some concerns that a $15 \%$ focus would produce "a quick-fix" approach with a focus on projects aiming at lifting areas from level 4 to 3. However, even though Aichi target 15 has a formulation about quantity, the target itself has a much wider focus on resilience, climate change mitigation and combating desertification. Having a strict focus on quantity and less on ecological restoration can in fact be in conflict with the other Aichi targets even though it may result in less degraded land. All 20 targets should be kept in mind and then quality of the restoration would be secured.

In conclusion, we may perhaps not judge any restoration project as not being relevant, except for those threatening biodiversity. However, even if a large range of projects can be considered as restoration of some kind this does not mean that they should be prioritized. The prioritysetting is where the "good" and "better" projects can be selected, based on the goal for the project. Some projects might even be biased in a way that they have diverging goals. The view on degradation/restoration may also shift over time. A historic example is the afforestation of heathland and stabilization of active dunes in southern Sweden in the late 19th and early $20^{\text {th }}$ century. At that time this was considered as restoration of over-used and spoilt habitats, even though these terms were not used (e.g. Kardell 2012). However, these efforts were so successful that today initiatives are made to restore back the heathland and dunes that were forest-planted and stabilized. In the same line; from a forestry perspec- 
tive the drainage of wet woodland is a way to improve the ecosystems function, while a biologist usually would see this as a loss of biodiversity.

\subsection{How to measure progress and to find the best descriptors?}

The levels in the EU 4-level model are based on a set of descriptors that are regarded typical for each level and characterizes the conditions of the ecosystem. A descriptor can have one or more indicators, and defines the threshold values between the levels (Lammerant et al. 2014). Such descriptors have already been implemented within the WFD (see chapter 4.1) for the identification of "good ecological status". Development of suitable descriptors and threshold values for the ecosystem types is the main challenge for further elaboration of the 4-level model (Lammerant, pers.comm.). Some priorities have been expressed, like state descriptors are preferred to "restoration measure"-descriptors and biotic are preferred to abiotic ones (see chapter 3). The measures of surface area seems to be quite essential for the 4-level approach.

Identification of relevant descriptors and indicators is critical and both research and management experience can contribute. Within the current Nordic project we have assessed if existing data and statistics on restored land are suitable, and partly looked into what descriptors or indicators are reported (cf. Table 5.1). We find it important to expand the view of relevant descriptors/indicators as long as they are relevant to describe status and progress of an indicators for successful restoration (= contribute to Aichi targets) in a wide sense. Relevant data may therefore come from ecology, society and economy, and it is essential to utilize any available data usable for direct or indirect links to restoration progress. Examples can be: number of ongoing (or finished) projects, money used, area of protected land (e.g. if protection is used to separate level 1 and 2), number of action plans and so on.

There is a need to measure progress on both large (national) scale and down to individual projects (local), and some descriptors might cover smaller or larger part of this range. In order to describe the conditions of a site the descriptors should be operative at a scale of relevance for restoration. The situation in Finland can be used as an example. In Finland, the impacts of forest- and peatland-habitat restoration are monitored to assess how well the restoration objectives have been realized (Similä \& Junninen 2012, Aapala et al. 2014). For this purpose an extensive network of monitoring sites has been set up around the country 
(Figure 5.2). The forest restoration network includes restored sites in moderately moist and semi-dry heathland forests together with a parallel set of control sites set up either in an unmanaged part of the same stand, or in a similar stand nearby. Monitored variables (comparable to descriptors in the 4-level model) in restored forests include living and dead trees, beetles and polypores (a group of fungi forming fruit bodies on trees) at sites where deadwood has been created, and living trees and tree seedlings where small canopy gaps have been opened. In addition a national network for the monitoring of the impacts of peatland restoration on hydrology and biodiversity has been set up. Restoration primarily aims to re-establish peatlands' natural hydrology, and hydrological monitoring involves direct observations of such trends. Hydrological trends are monitored after restoration using devices that automatically measure water levels between May and September. The chemical properties of water samples are collected and analyzed three times during the snow-free season. The impacts of peatland restoration on watercourses downstream are monitored in Central Finland and Northern Ostrobothnia. The quantities of runoff discharged from restored peatlands are monitored using automatic data logging devices, and they are also regularly measured manually at selected weirs. Water quality parameters including $\mathrm{pH}$ and nutrient concentrations are monitored in runoff samples collected during the snow-free period. All these parameters are recorded and reported into the monitoring system as national parameters, and at the same time they are valuable for follow-up and evaluation of the situation in single projects. Such standardized descriptors will allow data from single projects to be merged and be a part of national strategies and create new knowledge of relevance for each project and for the national target (see also chapter 6). 
Figure 5.2: Dead wood monitoring. In Finland, the effects of dead wood restoration on biodiversity (e.g. polypores and beetles) have been monitored since 2004

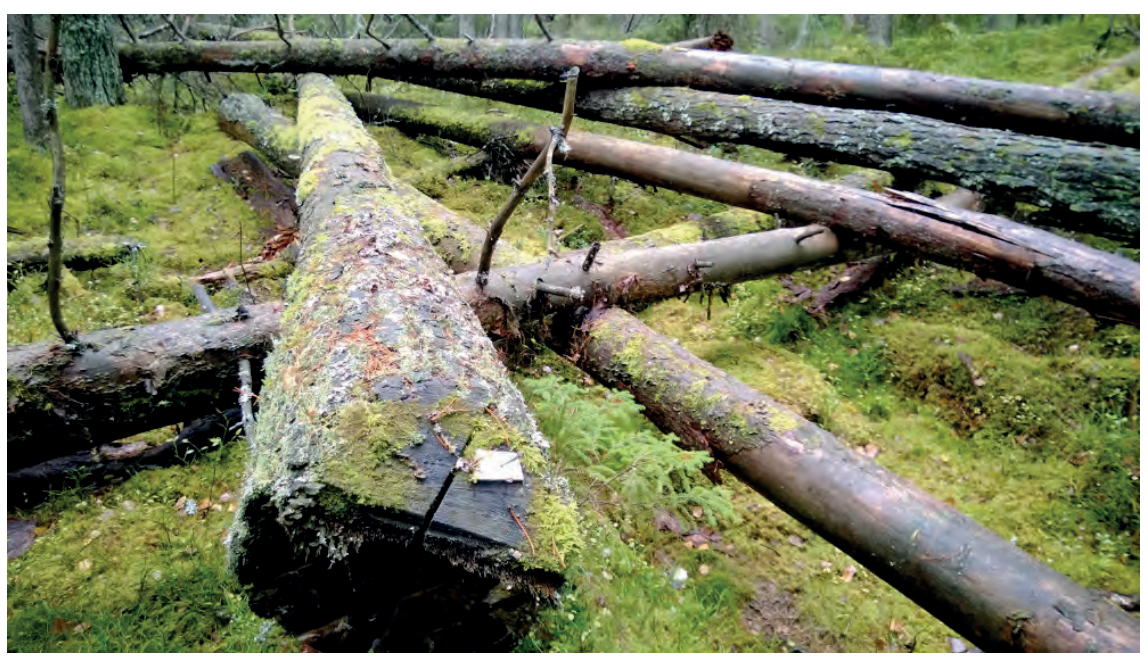

Photo: Jussi Päivinen.

\subsection{Achievements and progress of restoration in the Nordic countries and Estonia}

Based on the idea of descriptors from the 4-level model we have assessed data and available statistics that might describe the status of restored land in the Nordic countries and Estonia (Table 5.1). We have been fully aware of the lack of data we would face, but we still think it is highly relevant to put the status together as this can give input to cooperation between countries to improve existing statistics, identify missing data and the potential to improve these, and to use the available data as a basis for future restoration strategies. 


\begin{tabular}{|c|c|c|c|c|c|c|c|c|c|c|}
\hline \multirow[t]{2}{*}{ Habitats } & \multicolumn{2}{|c|}{ Estonia } & \multicolumn{2}{|c|}{ Finland } & \multicolumn{2}{|c|}{ Iceland } & \multicolumn{2}{|c|}{ Norway } & \multicolumn{2}{|c|}{ Sweden } \\
\hline & $\begin{array}{r}\text { Restored } \\
\text { land } \\
(\mathbf{k m} 2)\end{array}$ & $\begin{array}{r}\text { Total } \\
\text { land } \\
\text { cover } \\
\text { km2 }\end{array}$ & $\begin{array}{r}\text { Restored } \\
\text { land } \\
(\mathbf{k m 2})\end{array}$ & $\begin{array}{r}\text { Total } \\
\text { land } \\
\text { cover } \\
\text { km2 }\end{array}$ & $\begin{array}{r}\text { Restored } \\
\text { land } \\
(\mathbf{k m 2})\end{array}$ & $\begin{array}{r}\text { Total } \\
\text { land } \\
\text { cover } \\
\text { km2 }\end{array}$ & $\begin{array}{r}\text { Restored } \\
\text { land } \\
(\mathrm{km} 2)\end{array}$ & $\begin{array}{r}\text { Total } \\
\text { land } \\
\text { cover } \\
\text { km2 }\end{array}$ & $\begin{array}{r}\text { Restored } \\
\text { land } \\
(\mathbf{k m 2})\end{array}$ & $\begin{array}{r}\text { Total } \\
\text { land } \\
\text { cover } \\
\text { km2 }\end{array}$ \\
\hline $\begin{array}{l}\text { Forests/ } \\
\text { woodland }\end{array}$ & $\begin{array}{r}\text { no } \\
\text { statistics } \\
\text { available }\end{array}$ & 22,500 & 200 & 152,290 & 192 & 1030 & $\begin{array}{r}\text { no } \\
\text { statistics } \\
\text { available }\end{array}$ & 123,234 & $\begin{array}{r}\text { no } \\
\text { statistics } \\
\text { available }\end{array}$ & 23,8656 \\
\hline $\begin{array}{l}\text { Croplands } \\
\text { (agricultural } \\
\text { land) }\end{array}$ & $\begin{array}{r}\text { no } \\
\text { statistics } \\
\text { available }\end{array}$ & 9,550 & $\begin{array}{r}\text { no } \\
\text { statistics } \\
\text { available }\end{array}$ & 27,073 & $\begin{array}{r}\text { no } \\
\text { statistics } \\
\text { available }\end{array}$ & 2,060 & $\begin{array}{r}\text { no } \\
\text { statistics } \\
\text { available }\end{array}$ & 9,729 & $\begin{array}{r}\text { no } \\
\text { statistics } \\
\text { available }\end{array}$ & 36,023 \\
\hline $\begin{array}{l}\text { Grasslands } \\
\text { (incl. } \\
\text { heathland) }\end{array}$ & 100 & 600 & 40 & 13,537 & 1,573 & 31,930 & 129 & 149,178 & $\begin{array}{r}\text { no } \\
\text { statistics } \\
\text { available }\end{array}$ & 31,521 \\
\hline Wetlands & $\begin{array}{r}20(+ \\
\text { passive) }\end{array}$ & 2,600 & 200 & 87,990 & 26 & 6,180 & $\begin{array}{r}\text { no } \\
\text { statistics } \\
\text { available }\end{array}$ & 19,458 & $\begin{array}{r}\text { no } \\
\text { statistics } \\
\text { available }\end{array}$ & 40,526 \\
\hline Freshwater & $\begin{array}{r}\text { no } \\
\text { statistics } \\
\text { available }\end{array}$ & 2,200 & $\begin{array}{r}\text { no } \\
\text { statistics } \\
\text { available }\end{array}$ & 33,842 & $\begin{array}{r}\text { no } \\
\text { statistics } \\
\text { available }\end{array}$ & 2,060 & $\begin{array}{r}\text { no } \\
\text { statistics } \\
\text { available }\end{array}$ & 22,701 & $\begin{array}{r}\text { no } \\
\text { statistics } \\
\text { available }\end{array}$ & 40,526 \\
\hline
\end{tabular}

Data are based on national sources (Data from the Ministry of the Environment for Estonia; http://www.metla.fi/julkaisut/metsatilastollinenvsk/index-en.htm for Finland; Aradottir et al. 2013 for Iceland; http://www.environment.no/ for Norway, statistics not available at a form to provide data for Sweden). For comparison the total area of each ecosystem type (from Hagen et al. 2013 for the Nordic countries and from the Ministry of the Environment for Estonia) is shown. Grassland and heathland includes both semi-cultural grasslands, coastal managed heathlands and alpine heath.

There is no official statistics on the progress of restored areas in Estonia. Data for restored wetlands and grasslands are collected from implemented restoration projects. Data on grassland and freshwater restoration are collected to Estonia's Environmental Agency's database. Forest data including protection status are stored in the national Forest Registry. Data on croplands are gathered in Estonian Agricultural Registers and Information Board. Database for nature conservation activities including restoration is planned to be developed in the next few years. The majority of the semi-natural habitat, forest and peatland restoration activities take place in protected areas (both state and private owned). Restoration of abandoned peat-mining areas to mire habitats takes place also outside protected areas.

In Finland most of the forest and peatland restoration activities are carried out in state and private owned protected areas, but also some restora- 
tion goes on outside protected areas. Nearly all forest and peatland restoration is done as a part of Finnish Forest Biodiversity Program METSO. ${ }^{14}$ Data of state own areas are based on GIS-system of Metsähallitus, while data from private owned forests are gathered from yearly METSO-reports. Grassland restoration data are collected under National Grassland Inventory program for private lands and GIS-system of Metsähallitus for state owned land. For restoration of freshwater and cropland area restoration data are not available.

A national review of ecological restoration in Iceland was carried out in 2010 (Halldórsson \& Aradottir 2011) as a part of the Nordic Reno project (Halldórsson et al. 2012). An expert group of restorationists reviewed and selected relevant data provided by public agencies, private companies, nongovernmental organizations (NGO), municipalities, and other known actors of restoration in Iceland that were asked for standardized information on their restoration projects including descriptions of them, their main objectives, size, types of interventions and cooperative parties. As the Soil Conservation Service of Iceland (SCSI) has been the single most active actor in restoration with over $80 \%$ of the restored land (Aradottir et al. 2013) the outcome relies heavily on its database. SCSI only reported areas larger than $10 \mathrm{~km}^{2}$ and a large birch woodland restoration project, Hekluskogar, was not included, thus the restored area reported is an underestimate (Halldórsson et al.2011).

In Norway there is no running statistics on the progress of restored areas. The forest inventory includes data on decaying wood and some other indicators that can be relevant for future forest restoration projects. Within the national system "State of the Environment for Norway" 15 there are suggested indicators for wetland (number of restored wetland) and forest (number and area of restored forests), but currently no data are available and the indicators are not yet developed. An indicator for freshwater (number of restored freshwater units) is developed within the WFD. An indicator for semi-cultural grassland and heathland is partly developed (number of managed areas) and is reported in Table 5.1 , but includes only the activities run by management authorities.

Although there are available data on restoration activities in different habitat types in Sweden, there is no data summarizing all restoration efforts that have been carried out in different ecosystems, and thus no

14 http://metsonpolku.fi/en/index.php

15 http://www.environment.no/ 
numbers have been provided in Table 5.1. Datasets that can be used to give part of the answer are those restoration activities carried out and financed by the EU Rural Development Program or by the EU LIFE fund. The Swedish Authority for Marine and Water Management has a database on freshwater restoration, and The Swedish Environmental Protection Agency has some data on restoration activities in protected areas and in the framework of Action Programs for Threatened Species. 


\section{Input for further work on national level and in local communities}

\subsection{National programs and individual, local projects must work together}

The overall ecological, social and economic outputs from restoration are recognized, and a part of the reason why the Aichi targets were formed. The outcome of each single project builds up the physical progress of restoration. Plans and strategies at a national and regional level are the key to add up the output from all activities to make up the full advantage and measurable progress towards the international target. However, to get restoration on the national agenda there is a need for support and understanding of the contribution to biodiversity and ecosystem services from lay people, decision makers and politicians. This support has to be created within local communities and from successful projects with an output that is appreciated by those directly involved. If local people become active partners in restoration projects they will be the best ambassadors for future projects (Burke \& Mitchell 2007). To address this further and aim for effective outcomes of restoration we need to work from both national and local levels - and from this gain an added value.

Available knowledge and data on restoration derive from: (1) general and broad scale national dataset and statistics, and (2) individual (small and large) projects. Experiences from the ReNo project and from the work on this report show that an overview of individual projects is hard to get unless these are part of national strategies or programs. The assessments from the ReNo project is so far the best available dataset for individual projects (references listed in chapter 2), but we know that a large number of projects, run by land-owners, small and local entrepreneurs or NGO's are going on without being systematically reported (Halldorsson et al. 2012). The unfortunate in this is that these experiences (good and bad) will not be transferred to new initiatives. The ReNo project, supported by the work on the current report, highlights the requirement of national initiatives and strategies in combination with individual projects in local 
communities. This realization can be developed into a "top-down and bottom-up" strategy for restoration (Figure 6.1).

Some descriptors are relevant for specific habitats on a national level - e.g. ecological descriptors for natural processes in forest (e.g. Figure 5.2). These can be measured as changes (for different habitats) in degraded land and could make a difference to the Aichi-15\% (see chapter 5). In this case we can consider this "top-down". However, the typical situation, in at least some of the habitats in most countries, is that the ongoing restoration is run as lots of small projects and interventions. Each individual project will hardly make a difference in the national statistics of degraded land, but they still give important contribution to the $15 \%$ target. Such projects can be educative, give new insight, and produce restoration of importance on other scales than the national. These projects can be initiated locally, from municipalities, NGO's, landowners etc., and can be considered "bottom-up". Improved coordination of these initiative can expect to produce better restoration projects with better outcome, including ecology, economy, logistics, and practical tools and all experiences can be merged and shared. One future initiative could be to establish national databases for single projects, based on input from those running the restoration projects. If this approach is developed into a focused strategy it can potentially contribute to regional and even national statistics on progress towards the $15 \%$ target. 
Figure 6.1: A schematic diagram on how top-down and bottom-up strategies play a role in proceeding towards the $15 \%$ Aichi target. It calls simultanously for national initiatives and strategies and for developing a tool to gather the outcome and experiences from single, local projects. These must then be merged and integrated into bottom-up-strategies

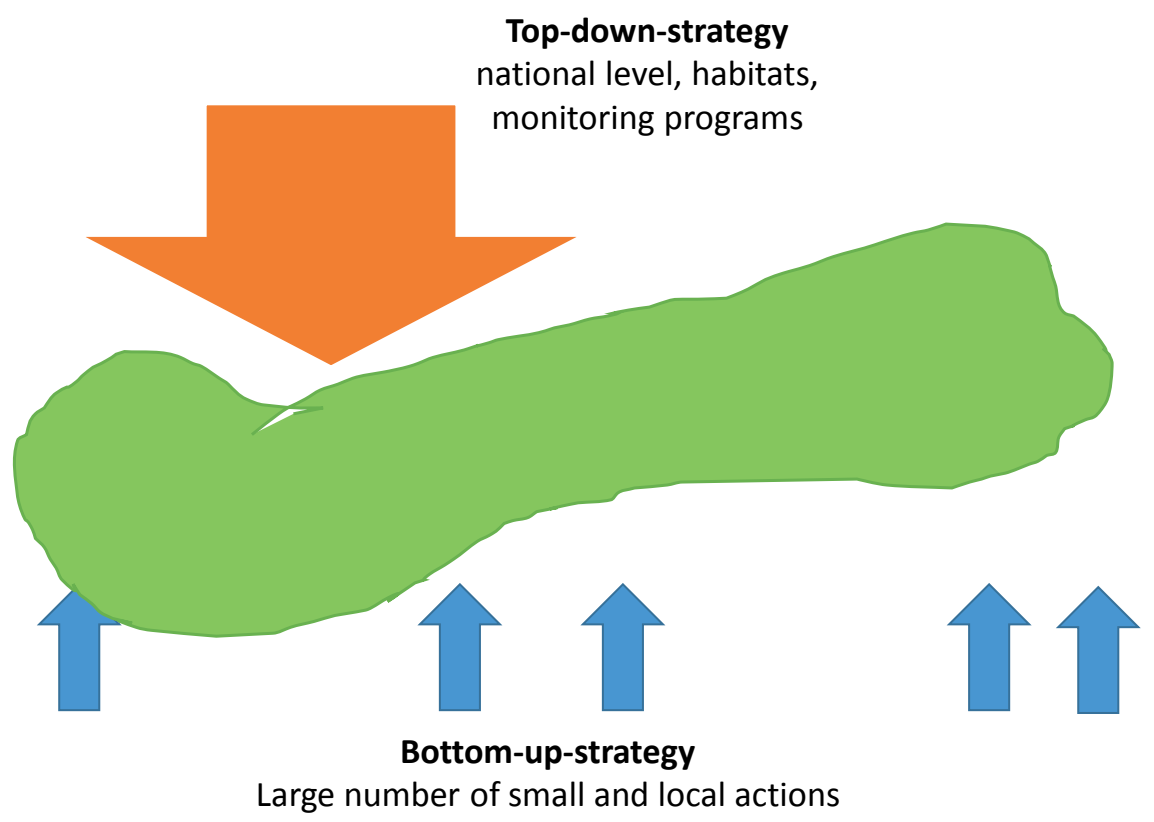

\subsection{Alternative way to achieve the target - the Finnish way}

Finland started a $15 \%$ restoration prioritization project in 2014. The project was set up by the Ministry of Environment. The main target was, by the end of the year 2015, to compose a proposal for strategic framework, in which a need of restoration prioritization in protected areas will be defined. To achieve the target, a restoration group (so called ELITE-group) was established. The ELITE group and sub-groups (e.g. forest, wetland, grassland) have members from ministries, state organizations and NGO's. In total more than 50 members are involved in these groups. The project has no specific funding, hence the cost (including salaries and travel expenses) of restoration group and sub-group members is covered by their employers.

When the project started the main question was how to achieve and document the achievement of the CBD Aichi target on restoration of 
$15 \%$ of degraded habitats in a way that is scientifically and ecologically valid. This lead to a 10 -step model which:

- empirically determine the current state of the habitats (steps 1-2)

- determine the degree of improvement in the state of the habitats that each of the restoration measures provide (steps 3-5)

- determine the cost of the restoration measures (steps 6-8), and finally

- illustrate how to achieve a prioritization of restoration actions based on the previous steps (steps 9-10).

The main difference compared to the 4-level-model (Lammerant et al. 2014 ) is that the 10 step model is not based on threshold values or categorization of habitat statuses, but rather utilizes continuous measurable variables, and as such it relies less on expert opinion type of information. The concept of the Finish strategy for restoration in protected areas was presented in a correspondence in "Nature" (Kotiaho et al. 2015). In addition to biodiversity, the model also takes into account ecosystem services (e.g. climate control, cultural values, food) and influence on employment.

The proposal for a national strategy for restoration in protected areas (by the end of 2015) will be the basis for more detailed plans and further actions to reach the $15 \%$ target in Finland. The utilization of existing data and monitoring programs will be a basis for strategies, and the involvement of stakeholders will allow for targeting specific activities at different scales. We encourage other countries and authorities to observe the progress made on the issue in Finland, and perhaps find input and inspiration for development of national strategies.

\subsection{How to make it happen?}

\subsubsection{Identifying Limiting factors}

Despite much more focus on ecological restoration and acknowledgements of its role in policies and management of natural resources (MEA 2005, Nordic Council of Ministers 2008, Hobbs et al. 2011), and its importance in counteracting degradation (e.g. Palmer et al. 2004), there are many obstacles. Factors that may prevent or limit restoration activi- 
ties include lack of ecological knowledge, availability of suitable tools and methodologies for restoration, policies and shortage of finances.

To initiate and undertake restoration projects several factors must operate. Analyses of ecological restoration in the Nordic countries revealed that habitat types pointed to methods used in restoration while socioeconomic drivers were more important in determining timing and locations of restoration projects (Hagen et al. 2013). This may indicate that ecological knowledge and methodology have become sufficient, at least on a broad scale, whereas social issues more often may limit restoration.

With increasing emphases on ecological restoration in local and international policies this should be improving, although prioritization towards restoration is often still needed. In the Nordic review there were some examples of restoration in areas were profitable activities were closed down, and also examples of governmental incentives that encourage management and intervention in conflict with restoration (Hagen et al. 2013). Ecological restoration can aim at producing very different values, including personal, ecological, socioeconomic and cultural values (Clewell \& Aronson 2013). As restoration ecology is still a young profession these values, and the philosophy and consequences related to the creation of them, is expected to develop further in the years to come. The increased attention and expectations from restoration ecology, e.g. from the Aichi targets, may influence the thresholds and limitation for socio-economic limiting factors. Financial incentives can be an important driver, e.g. as seen in the impact of a special funding for land reclamation and conservation in 1974 when celebrating 1,100 years of settlement in Iceland (Aradottir et al. 2013), and how restoration in the EU member states of the Nordic countries have greatly benefitted EU-Life funding (Hagen et al. 2013).

In future restoration the identification of limiting factors have to be accomplished both at national and local levels. At the national scale limiting factors must be identified to formulate strategies to overcome them and to allow for prioritization and formulating realistic strategies. The conclusion from the ReNo-project (Hagen et al. 2013) can be a first step for such work, and should proceed more in detail for each country (and perhaps each habitat). Also within individual projects there is a need to identify limiting factors. This needs to be the basis for formulating realistic goals, and further for the achievements and the acceptance of the output from restoration. Successful restoration projects at local scale is essential for support and enthusiasm, and promote a positive helix for this type of activity. 


\subsubsection{The importance of prioritizing}

Regardless of how much time or other resources we have, prioritizing is essential, and of course more so when the resources are much less than needed. This is very much the case when it comes to the ambitions for restoring degraded ecosystems. Even if we abandon the $15 \%$ target or all land that is not in a good ecological condition is included in the «restorable» baseline, the challenge to identify functional priorities for the work with ecosystem restoration is still large. Which ecosystems are most important to work with? How high should the ambitions be? Should the focus be on the most degraded ecosystems, where the ecosystems basic functions may be lost, or on the ones that are most likely to hold valuable habitats or species in the near future? If there is one budget for restoration, how can different ecosystem groups be compared? It is hard to find robust parameters that can indicate whether a threatened dune habitat is more relevant to restore than an equally threatened forest habitat.

A framework and a guidance system for priorities is described as a separate session in the EU-project report. "Guidance for priority setting at sub-national and national level" (Lammerant et al. 2013). Although the report is rather general, it can give systematic support when working further on prioritization, and suggest a way to organize this: (i) identification of target group, (ii) identification of potential criteria, (iii) identification of existing frameworks, approaches and tools and (iv) the needs for assessment of priority setting across scales.

A set of criteria for priority was identified as being important by the EU-working group:

- The status of the habitats.

- The pressure on the habitats.

- The chance of success (ecological and social).

- The relationship with other stakeholders and access to money for specific problems or habitats.

In our current project we have not gone further into the discussions about priorities. The issue is closely related to funding and economy of restoration, and the relationship between area (quantity) and that some areas have higher biodiversity values (quality). The ReNo-project showed that most restoration projects are funded by public money, and $\mathrm{EU}$ is a strong driver for big restoration programs and initiatives (Hagen et al. 2013). In all the Nordic countries private funding contributes to 
ecological restoration, sometimes as part of larger development projects with private interests. Both NGOs and idealistic initiatives contributes to some restoration in all Nordic countries. The development of models for priority setting is highly relevant for the national strategies of restoration. We recommend that this should be given attention in future work, perhaps as an extension of the current project.

A recent study based on the review of 225 restoration projects concludes that the economic benefits from restoring natural ecosystems outweigh the cost (De Groot et al. 2013). This is valuable findings as it has traditionally been assumed that restoration is costly and thus draws resources from a community. When focusing on the economic values of the services provided by intact habitats it can be shown that the benefits from these in many cases are higher than restoration cost. As a single ecological service may conflict with biodiversity conservation it is important to ensure multi-functionality in such restoration projects (Bullock et al. 2011, Suding 2011). The De Groot et al. (2013) study should be an additional encouragement for supporting and give priority to restoration in the Nordic countries. 



\section{Actions for more effective restoration in the Nordic countries and Estonia}

Based on the work in this project, including available data and discussions in the group, we have listed some actions of relevance for the Nordic countries and Estonia in the further work towards more effective restoration. The actions are listed randomly, and not in order of priority.

1. The need for a restoration vision and a national plan.

A progress towards the Aichi 15 target calls for a restoration vision in each country. Working out a vision will give the opportunity to discuss ideas and level of ambitions. The vision must be the basis for the next step, to formulate a national plan for ecological restoration. This work should be seen in the context of favorable conservation status and green infrastructure. The points listed below would be relevant for such a plan. The ongoing Finnish work with a national plan for restoration could be an example for inspiration to other countries, but each country must relate such vision and plan to distinctive national characteristics and needs.

2. Priority setting.

In a situation of limited resources for restoration it is essential to develop good models for priority setting. Such models must identify the most important and the most urgent projects, habitats or areas. Good and responsible priority setting must aim for the best use of available funding, solving the most urgent problems, and optimal protection and restoration of biodiversity in a national context.

3. Integration and cooperation.

Restoration must be integrated into all sectors of land-use management and not be considered as a separate activity outside ongoing development. Different interests, stakeholders and professions will together make up the knowledge and experience needed to formulate realistic goals for restoration. The need for and relevance of levelling of definitions and statistics between countries 
should be assessed. Cooperation between countries on these issues has also proved to be very useful for information exchanges, and this applies between and among all different stakeholders.

4. Focus on restoration activities and output.

Statistics on degraded land and progress of restoration is relevant to define baseline, to measure activity and to argue for money/support for new projects. However, the statistics itself must not take the focus away from what this really is about: to head towards better and more restoration of natural values, and to reduce degraded land. The focus should not be so much on the $15 \%$ target per se, but should be used as a way to get the attention from decision makers and a motivation to enhance restoration.

5. Top-down and bottom up.

More and improved restoration will need initiatives at the national level (as strategic plans and programs) and integration of all the local initiatives. Much ongoing restoration in the Nordic countries and Estonia are small projects carried out in local communities. Each of these will hardly contribute to the $15 \%$ target, but together they are essential for the progress. The importance of the small projects can be recognized by including other types of descriptors that area restored (like number of projects, money used, or man-hours used).

6. Identify limiting factors.

The identification of limiting factors is essential for effective restoration, both at national and individual project levels. Procedures to identify or reveal the ecological, social, economic, and structural limitation should be developed for countries/habitats. Based on assessments aimed at identifying and overcoming these limitations restoration will have better chance to succeed.

7. Formulate descriptors to use in statistics on progress.

The formulation of measurable descriptors is a key for measuring progress. Existing statistics and related parameters must be assessed to see how relevant they are for measuring the progress of restoration. We have indicated how this can be done, and suggested how to continue the work. Evaluation and continuous assessment of ongoing projects is an effective way to learn from them, and bring this into future projects (including topics like ecology, technology/methods, planning and organizing). 


\section{References}

Aapala, K., Similä, M. \& Penttinen, J. (eds.). (2012). Ojitettujen soiden ennallistamisopas. Metsähallituksen luonnonsuojelujulkaisuja. Sarja B 188. p. 301 s. http://julkaisut.metsa.fi/julkaisut/show/1601

Aapala, K., Similä, M. \& Penttinen, J. (eds.). (2014). Ecological restoration in drained peatlands - best practices from Finland. Nature Protection Publications of Metsähallitus. 27 pp. http://julkaisut.metsa.fi/julkaisut/show/1733

Aradottir, A. L., \& Arnalds, O. (2001). Ecosystem degradation and restoration of birch woodlands in Iceland. Pages 295-308 in F. E. Wielgolaski, editor. Nordic mountain birch ecosystems. UNESCO, Paris, France, and Parthenon, Carnforth, UK.

Aradottir, Á. L. \& Hagen, D. 2013. Ecological Restoration: Approaches and Impacts on Vegetation, Soils and Society. Advances in Agronomy. Vol. 120, 173-222. http://dx.doi.org/10.1016/B978-0-12-407686-0.00003-8

Aradóttir, Á. L. \& Halldórsson, G. (eds.). (2011). Vistheimt á Íslandi [Restoration in Iceland]. Agricultural University of Iceland and Soil Conservation Service of Iceland. 165 pp. http://pdfvef.oddi.is/landgraedslan/vistheimt_a_islandi/

Aradóttir, Á. L., Petursdottir, T., Halldorsson, G., Svavarsdottir, K. \& Arnalds, O. (2013). Drivers of ecological restoration: lessons from a century of restoration in Iceland. Ecology and Society 18(4): 33. http://dx.doi.org/10.5751/ES-05946-180433

Arnalds, A. (1987). Ecosystem disturbance in Iceland. Arctic and Alpine Research 19: 508-513.

Arnalds, O. \& Barkarson, B. H. (2003). Soil erosion and land use policy in Iceland in relation to sheep grazing and government subsidies. Environmental Science \& Policy 6:105-113. http://dx.doi.org/10.1016/S1462-9011(02)00115-6

Arnalds, Ó., Porarinsdóttir, E. F., Metusalemsson, S., Jonsson, A., Gretarsson, E. \& Arnason, A. (2001). Soil erosion in Iceland. The Soil Conservation Service and the Agricultural Research Institute, Reykjavík, Iceland. http://www.rala.is/desert/ Soil\%20Erosion.pdf

Aronson, J., Floret, C., LeFloc'h, E., Ovalle, C., \& Pontanier, R. (1993). Rehabilitation of degraded ecosystems in arid and semi-arid lands. I. A view from the South. Restoration Ecology 1, 8-17. Http://dx.doi.org/10.2307/1551417

Baker, S., and K. Eckerberg. (2013). A policy analysis perspective on ecological restoration. Ecology and Society 18(2): 17. http://dx.doi.org/10.5751/ES-05476-180217

Benayas, J. M. R., Newton, A. C., Diaz, A. \& Bullock, J. M. (2009). Enhancement of biodiversity and ecosystem services by ecological restoration: a meta-analysis. Science 325, 1121-1124. http://dx.doi.org/10.1126/science.1172460

Bjarnason, H. (1974). Comments on the history of Icelanders in relation to woodland destruction. Yearbook the Icelandic Forestry Association: 30-43. In Icelandic with English summary.

Bradshaw, A. D. (1983). The reconstruction of ecosystems. Journal of Applied Ecology 20, 1-17. http://dx.doi.org/10.2307/2403372 
Bullock, J. M., Aronson, J., Newton, A. C., Pywell, R. F. \& Rey-Benayas, J. M. (2011). Restoration of ecosystem services and biodiversity: conflicts and opportunities. Trends in Ecology and Evolution 26, 541-549. http://dx.doi.org/10.1016/ j.tree.2011.06.011

Burke, S.M., Mitchell, N. (2007). People as ecological participants in ecological restoration. Restoration Ecology 15, 348-350. http://dx.doi.org/10.1111/j.1526100X.2007.00223.x

Certain, G., Skarpaas, O., Bjerke, J.-W., Framstad, E., Lindholm, M., et al. (2011). The Nature Index: A General Framework for Synthesizing Knowledge on the State of Biodiversity. PLoS ONE 6(4): e18930. http://dx.doi.org/10.1371/journal.pone.0018930

Clewell, A. F. \& Aronson, J. (2013). Ecological restoration: principles, values, and structure of an emerging profession. 2nd edition. Island Press, Washington. http://dx.doi.org/10.5822/978-1-59726-323-8

Comín, F. A. (2010). The challenges of humanity in the twenty-first century and the role of ecological restoration. In: Ecological Restoration. A global challenge (F. A. Comín, ed.), pp. 3-20. Cambridge University Press, Cambridge.

De Groot, R. S., Blignaut, J., Van Der Ploeg, S. et al. (2013). Benefits of Investing in Ecosystem Restoration. Conservation Biology. http://dx.doi.org/10.1111/cobi.12158

Fosaa, A. M., \& Simonsen, W. (eds.). (2011). Lendisnýtsla i Føroyum [Land use activities in the Faroe Islands]. Faroese Museum of Natural History, Tórshavn, Faroe Islands.

Hagen, D. \& Skrindo, A.B. (eds.). (2010). Restaurering av natur i Norge. Et innblikk $i$ fagfeltet, fagmiljøer og pågående aktivitet. NINA Temahefte 42: 109 pp. Norsk institutt for naturforskning (NINA), Trondheim.

Hagen, D., Svavarsdottir, K., Nilsson, C., Tolvanen, A., Raulund-Rasmussen, K., Aradottir, A.L., Fosaa, A.M. \& Halldórsson, G. (2013). Ecological and social dimensions of ecosystem restoration in the Nordic countries. Ecology and Society 18(4): 34. http://dx.doi.org/10.5751/ES-05891-180434

Hagen, D. \& Evju, M. (2013). Using short-term monitoring data to achieve goals in a large-scale restoration. Ecology \& Society 18(3): 29. http://dx.doi.org/10.5751/ES05769-180329

Halldórsson, G., Aradóttir, A.L., Fosaa, A.M., Hagen, D., Nilsson, C., RaulundRasmussen, K. Skrindo, A.B., Svavarsdóttir, K. \& Tolvanen, A. (2012). ReNo. Restoration of damaged ecosystems in the Nordic countries. TemaNord 2012:558, 68 pp. http://dx.doi.org/10.6027/TN2012-558

Halldórsson, G., Svavarsdóttir, K., Pórarinsdóttir, E. F. and Runólfsson, S. (2011). Vistheimt á vegum Landgræðslu ríkisins [Ecological restoration by the Soil Conservation Service of Iceland]. In: Aradóttir, Á. L. and Halldórsson, G. (eds.), Vistheimt á Íslandi [Ecological restoration in Iceland]. Landbúnaðarháskóli Íslands \& Landgræðsla ríkisins, Reykjavík, Iceland, pp. 40-48.

Hobbs, R. J., Hallett, L. M., Ehrlich, P. R. \& Mooney, H. A. (2011). Intervention Ecology: Applying Ecological Science in the Twenty-first Century. Bioscience 61: 442-450. http://dx.doi.org/10.1525/bio.2011.61.6.6

Johansson, E. (2011). Do restoration projects reach their goals? A study of Swedish LIFE restoration projects. Master's thesis. Department of Ecology and Environmental Science, Umeå University.

Kardell, L. (2012). Ljungheden I Vrå socken och Skogsssällskapet. Publication no 114 (2012) in the report series from Institutionen för skoglig landskapsvård, Sveriges lantbruksuniversitet, Uppsala.

Kotiaho, J. S., Halme, P., Kareksela, S., Oldén, A., Haapalehto, T., Päivinen, J. \& Moilanen, A. (2015). Target for ecosystem repair is impractical. Nature 519: 33. 
Lammerant, J., Peters, R., Snethlage, M., Delbaere, B., Dickie, I. \& Whiteley, G. (2014). Implementation of 2020 EU Biodiversity Strategy: Priorities for the restoration of ecosystems and their services in the EU. Report to the European Commission. ARCADIS (in cooperation with ECNC and Eftec). http://ec.europa.eu/environment/ nature/biodiversity/comm2006/pdf/2020/RPF.pdf

MEA. (2005). Ecosystems and Human Well-being: Biodiversity Synthesis. World Resources Institute, Washington DC.

Min, S.-K., Zhang, X., Zwiers, F.W. \& Hegerl, G.C. (2011). Human contribution to moreintense precipitation extremes. Nature 470, 378-381, http://dx.doi.org/10.1038/nature09763

Mitsch, W. J., \& Jorgensen, S. E. (2003). Ecological engineering: A field whose time has come. Ecol. Eng. 20, 363-377. http://dx.doi.org/10.1016/j.ecoleng.2003.05.001

Morsing, J., Frandsen, S.I., Vejre, H. \& Raulund-Rasmussen, K. (2013). Do the Principles of Ecological Restoration Cover EU LIFE Nature Cofunded Projects in Denmark? Ecology and Society 18(4): 15. http://www.ecologyandsociety.org/ vol18/iss4/art15/

Nordiska ministerrådet. (2013). Ett gott liv i ett hållbart Norden. Nordisk strategi för hållbar utveckling. ANP 2013:725. http://dx.doi.org/10.6027/ANP2013-725

Normander, B., Levina, G., Auvinen, A.-P., Bratli, H., Stabbetorp, O., Hedblome, M., Glimskäre, A. \& Gudmundsson. G.A. (2012). Indicator framework for measuring quantity and quality of biodiversity-Exemplified in the Nordic countries. Ecological Indicators 13, 104-116. http://dx.doi.org/10.1016/j.ecolind.2011.05.017

Nybø, S., Certain, G. \& Skarpaas, O. (2011). The Norwegian Nature Index 2010. DNreport 2011-1.

Óskarsson, H. (2009). Hekluskogar: Islands største reetablering af birkeskove. Skoven 41 (1): 35-39.

Palmer, M., Bernhardt, E., Chornesky, E., Collins, S., Dobson, A., Duke, C., Gold, B., Jacobson, R., Kingsland, S., Kranz, R., Mappin, M., Martinez, M. L., Micheli, F., Morse, J., Pace, M., Pascual, M., Palumbi, S., Reichman, O. J., Simons, A., Townsend, A. \& Turner, M. (2004). Ecology for a crowded planet. - Science 304: 1251-1252.

Pedersen, M. L., Andersen, J. M., Nielsen, K. \& Linnemann, M. (2007). Restoration of Skjern River and its valley: project description and general ecological changes in the project area. Ecological Engineering 30:131-144.

http://dx.doi.org/10.1016/j.ecoleng.2006.06.009

Schiermeier, Q. (2011). Increased flood risk due to global warming, Nature 470, 316, http://dx.doi.org/10.1028/470316a

SER, Society for Ecological Restoration Science \& Policy Working Group. (2004). The SER International Primer on Ecological Restoration. Society for Ecological Restoration International. Available at: http://www.ser.org/content/ ecological_restoration_primer.asp

Sigurdsson, S. (1977). Birch in Iceland. In: Gudmundsson, H., Ragnarsson, H., Thorsteinsson, I., Jonsson, J., Sigurdsson, J. and Blöndal, S. (eds.), Skógarmál. Edda, pp. 146-172. In Icelandic.

Similä, M. \& Junninen K. (eds.) 2011: Metsien ennallistamisen ja luonnonhoidon opas. Metsähallituksen luonnonsuojelujulkaisuja. Sarja B 157. p. 191.

http://julkaisut.metsa.fi/assets/pdf/lp/Bsarja/b157.pdf

Similä, M. \& Junninen K. (eds.) 2012. Ecological restoration and management in boreal forests - best practices from Finland. Nature Protection Publications of Metsähallitus. 54 pp. http://julkaisut.metsa.fi/assets/pdf/lp/Muut/ecologicalrestoration.pdf 
Skarpaas, O., Certain, G. \& Nybø, S. (2012). The Norwegian Nature Index - conceptual framework and methodology, Norsk Geografisk Tidsskrift - Norwegian Journal of Geography 66, 250-256.

Suding, K. N. (2011). Toward an era of restoration in ecology: successes, failures, and opportunities ahead. Annual Review of Ecology, Evolution, and Systematics 42, 465-487. http://dx.doi.org/10.1146/annurev-ecolsys-102710-145115

TEEB. (2010). The Economics of Ecosystems and Biodiversity: Mainstreaming the Economics of Nature: A Synthesis of the Approach, Conclusions and Recommendations of TEEB. TEEB Central Office, UNEP, Geneva.

Thorsteinsson, I., Olafsson, G. \& van Dyne, G.M. (1971). Range resources of Iceland. Journal of Range Management 24: 86-93. http://dx.doi.org/10.2307/3896512

Traustason, B. \& Snorrason, A. (2008). Spatial distribution of forests and woodlands in Iceland in accordance with the CORINE land cover classification. Icelandic Agricultural Sciences 21: 39-47.

Whisenant, S. G. (1999). Repairing Damaged Wildlands. Cambridge University Press, Cambridge. http://dx.doi.org/10.1017/CB09780511612565

Young, T. P., Petersen, D. A. \& Clary, J. J. (2005). The ecology of restoration: historical links, emerging issues and unexplored realms. Ecological Letters 8, 662-673. http://dx.doi.org/10.1111/j.1461-0248.2005.00764.x

Zedler, J. B. (2007). Success: an unclear, subjective descriptor of restoration outcomes. Ecological Restoration 25, 162-168. http://dx.doi.org/10.3368/er.25.3.162 


\section{Sammendrag}

\section{Det nordiske Aichi restaureringsprosjektet}

Hvordan kan Norden operasjonalisere CBD-målet om restaurering av $15 \%$ av ødelagte økosystemer innen 2020 ?

Konvensjonen om biologisk mangfold forplikter medlemslandene til å stanse tapet av biologisk mangfold innen 2020. For å gjennomføre denne oppgaven er det formulert 20 mål (de såkalte Aichi-målene) der to av dem retter seg direkte mot restaurering av ødelagte økosystemer. Dette kommer klarest fram i mål 15 som sier at innen år 2020 skal $15 \%$ av degraderte økosystemer være restaurert. Økologisk restaurering er definert som "tiltak som bidrar til istandsetting av økosystem som har blitt degradert, forstyrret eller ødelagt," for å gjenopprette helse, integritet og bærekraftige økosystemer. Alle de nordiske landene er parter i Konvensjonen om biologisk mangfold og har forpliktet seg til å jobbe for å nå Aichi-målene. I tillegg har landene nasjonale miljømål som drar i samme retning som de internasjonale forpliktelsene. Dette prosjektet tar opp i seg tradisjonen og den felles interessen for miljøsamarbeid som finnes i de nordiske landene.

Målet med prosjektet er å gi et faglig grunnlag for myndighetene i de nordiske landene i arbeidet med å nå Aichi-mål 15 om restaurering av økosystemer. Rapporten beskriver muligheter, begrensninger og utfordringer for hvordan restaurering kan bidra til Aichi-målene, basert på tilgjengelig kunnskap, eksisterende statistikk om forringede områder og pågående restaurering i Norden og Estland. Det er en klar intensjon at prosjektet skal bidra til videre arbeid på nasjonalt nivå og ute i lokalsamfunnene.

Prosjektet "Restaurering i Nordiske land - ReNo" ble støttet av Nordisk ministerråd og TEG (2009-2011) og har sammenstilt en oversikt over status for pågående restaurering på Nordisk regionalt nivå. ReNo har vært avgjørende for å gjennomføre det nordiske Aichi-prosjektet. I tillegg har arbeidet med utvikling av en konseptuell 4-nivå modell for restaurering av økosystemer i EU vært et svært nyttig bidrag i arbeidet vårt.

Konseptet ødelagt eller forringet areal er vesentlig for å kunne måle framgang mot $15 \%$-målet. Her har vi sett på hvorvidt eksisterende statistikk kan brukes for å tallfeste forringet areal fordelt på land og økosystemtyper. Det viste seg at tilgjengelige data er basert på ulike typer statistikk og ulike definisjoner på graden av forringet areal. Dataene kan der- 
for ikke brukes direkte for å beskrive den faktiske situasjon og de har også begrenset verdi for sammenlikning mellom land. Derimot viser denne $\emptyset$ velsen at dersom det er ønskelig er det mulig å utvikle tankegangen videre og kanskje standardisere dataene så de fyller dette formålet.

For å kunne måle og rapportere framgang for restaurering er det nødvendig å ha klart definerte parametere og indikatorer. Vi har vurdert om eksisterende data og statistikk om restaurert areal i Norden og Estland er egnet for dette formålet. Tilgjengelige data om restaurering finnes som: (1) generelle nasjonale datasett og statistikk, og (2) spredte opplysninger om individuelle (små og store) prosjekter. Det er helt åpenbart behov for å se nasjonale initiativ og strategier i sammenheng med enkeltprosjekter som pågår rundt omkring i landene. Dette bør utvikles til en systematisk "top-down og bottom-up" strategi for restaurering. Det er svært mangelfulle eksisterende data om pågående restaureringsaktiviteter og utviklingen innen restaurering. Tross sine mangler tror vi likevel at denne sammenstillingen har en verdi ved at den øker bevisstheten rundt mangelen på data og viser behovet for samarbeid mellom landene for å forbedre eksisterende statistikk, identifisere manglende data og bruke tilgjengelige data som utgangspunkt for framtidige restaureringsstrategier.

Finland er så langt det eneste nordiske landet som har etablert et nasjonalt råd for prioritering av restaurering. I løpet 2015 vil dette rådet foreslå en nasjonal strategi rettet mot $15 \%$ målet. De andre landene bør holde seg oppdatert på dette arbeidet og bli inspirert av Finland til å utvikle egne nasjonale strategier.

Prosjektet har foreslått sju tiltak som vi mener er relevante for å utvikle mer effektiv restaurering i Norden og Estland: 1. Arbeidet med Aichi-mål 15 vil kreve en klar visjon og nasjonale planer for økologisk restaurering; 2. I en situasjon med begrensede ressurser til restaurering må det utvikles gode modeller for å gjøre prioriteringer; 3 . Integrering og samarbeid er helt nødvendig for å formulere realistiske mål for restaurering og restaurering må integreres i alle sektorer som berører arealbruk og forvaltning; 4 . Det er viktig å ha fokus på selve restaureringsaktivitetene, slik at det å oppnå $15 \%$ i seg selv ikke tar fokus bort fra det aller viktigste, nemlig bedre og mer restaurering; 5 ; Mer og bedre restaurering vil både kreve innsats på nasjonalt plan (gjennom nasjonale planer og programmer) og integrering av alle lokale initiativ i en integrert topdown og bottom up tilnærming; 6. Prosedyrer for å identifisere begrensende faktorer for vellykket restaurering bør utvikles for land og habitater; 7. Det må utvikles målbare indikatorer/deskriptorer som kan brukes i statistikk for å måle framgang for restaurert areal. 
Nordic Council of Ministers

Ved Stranden 18

DK-1061 Copenhagen K

www.norden.org

\section{The Nordic Aichi restoration project}

The Convention of Biological Diversity commits the parties to halt the loss of biodiversity within 2020. For accomplishing this task, the Aichi targets have been established. Aichi target 15 aims at restoring 15\% of damaged ecosystems by 2020 . The Nordic countries are parties to CBD, and committed to the Aichi targets. This project will establish a basis that may be used by the management and political authorities in the Nordic countries for achieving Aichi target 15 on restoration of degraded ecosystems. The report explores the possibilities, limitations and challenges on how ecological restoration can contribute to the Aichi target, based on available knowledge and existing statistics on degraded land and restoration experiences in the Nordic countries and Estonia. This is intended as a contribution for future work at the national level and in local communities.

TemaNord 2015:515

ISBN 978-92-893-3974-2 (PRINT)

ISBN 978-92-893-3976-6 (PDF)

ISBN 978-92-893-3975-9 (EPUB)

ISSN 0908-6692

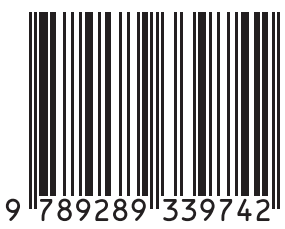

